\title{
El lèxic taurí dels segles XVIII i XIX: a propòsit de toro, bou, brosquil, corro i altres termes
}

\author{
Johquim Martí Mestre \\ Universitat de València / Institut Interuniversitari de Filologia Valenciana \\ joaquin.mart@uv.es \\ Recibido: noviembre de 2013. Aceptado: diciembre de 2013
}

Resum: La intenció d'aquest article és proporcionar noves dades i complementar la informació que ofereixen els diccionaris històrics i etimològics per relació a una sèrie de termes vinculats amb els toros, així com demostrar el valor dels textos literaris de vocació popular en la història del lèxic català. Aportem documentació que ajude a estudiar la cronologia i la motivació dels canvis experimentats per toro i bou, així com informació sobre altres mots relacionats (boual, bouero, brau, novillo / novello), i expressions com bou de foc. Les dades proporcionades permeten comprovar que brosquil ha estat ben conegut en la zona central del País Valencià. Aportem, així mateix, nous fonaments per a la història dels mots corro (i l'expressió relacionada corre de toros, i variants) i garranxó, en relació amb el món taurí.

Paraules clau: Història del lèxic català, lèxic modern i contemporani, vocabulari taurí, vocabulari popular, situació del lèxic al País Valencià, relació amb el lèxic castellà.

\begin{abstract}
This article explores the history of some words associated with bulls. Our intention has been to provide new data and complement the information of the historical and etymological dictionaries as well as to demonstrate the value of literary popular texts in the history of the Catalan lexicon. We provide documentation that contributes to the study of the chronology and causality of changes of the words. At the same time, the article provides new documentation and information about other related words (boual, bouero, brau, novillo / novello), and expressions like bou de foc. The provided data allow to verify that brosquil has been a well-known word in the central area of the Valencian Country. We provide also new bases for the history of the words corro (and the expression corre de toros, and its variants) and garranxo.
\end{abstract}

Keywords: History of the Catalan lexicon. Modern and contemporary lexicon. Bullfighting vocabulary. Popular vocabulary. Status of the lexicon in the Valencian Country. Relationship with the Spanish Lexicon. 
1. Tenim notícies documentals de festes taurines en terres valencianes des de l'època medieval. Les més antigues que es citen són les celebrades l'any 1373 per la visita a la ciutat de València de l'infant Joan, futur rei Joan I (Graullera 1999: 77). ${ }^{1}$ Els jocs de toros, celebrats amb motiu de visites reials o simplement per festes de la ciutat, hi tingueren sempre una gran acollida popular, a pesar de les crítiques que, amb diferents arguments, han rebut històricament. ${ }^{2}$ Els autors de dietaris i llibres de memòries dels segles XV, XVI i XVII solen recollir notícies sobre corregudes o jocs de toros celebrats a València, com es pot comprovar en Melcior Miralles, en Jeroni Sòria, en Joaquim Aierdi, i, sobretot, en Pere Joan Porcar. Al segle XVIII, se'n fan ressò els col-loquis, alguns dels quals estan centrats, precisament, en aquestes festivitats.

Així ocorre en quatre col-loquis de Carles Ros: Romanç nou, graciós y entretengut en què.s declara la rinya, junta y delliberació que lls toros acordaren, imediatos a la torada, ans de partir per a València, per a la correguda dels dies 13, 14 y 15 d'este mes de octubre y present any de 1738, en què esta illustre ciutat celebra lo segle $V$ de sa gloriosa Conquista, s. 1. [València], s. a. [1738]; Nova y gustosa relació, jocós y divertit romanç, en què es veu lo corro de toros de la plaza de Sent Domingo de esta ciudad de València, en lo dia 11 de setembre de este present any de 1741, s. 1. [València], s. a. [1741]; Romanç entretengut sobre la correguda de bous en sarauuells qu'en les festes al beneÿt Sent Roch, del carrer de la Corona de la ciutad de València, s'han fet, en los dies 21 y 22 del mes de octubre de l'any 1752 (ed. Barberà, 1905: 171-176), i Romans nou de la correguda de baques y bedells, feta en un camp, prop de la Zaidia, tocant als murs de València, en los dies 22, 24, 25, 26, 29 y 30 de setembre any 1755, hon graciosament se conta el sucés, per a entretindre el temps aprés de acomodada la panja de bona menjusa y suc de raïm, València, imp. de Agustín Laborda, s. a.

També són de temàtica taurina dos col-loquis manuscrits inclosos en el ms. 6781 del fons «Serrano Morales» de la Biblioteca Municipal de València: el Coloqui entre dos llauradors sobre els bous de la Alamera, de 1748 (ms. 6781, BMV, fons) i el Coloqui dels carafals, que conegué versions impreses als segles XVIII i XIX. Del segle XIX, coneixem també el romanç manuscrit intitulat Corrida de toros del lunes 19 de setiembre de 1831 (BMV, ms. 6781), que, tot i portar el títol en castellà, està redactat íntegrament en català. ${ }^{3}$ Encara que no tracta només dels toros, el Coloqui per a la festa de Nostra Senyora de la Esperanza en lo any 1730, que es féu dins lo convent de Senta Úrsola de València (Furió, 2001), fa referència també, en part, a la correguda o corro de bous.

\footnotetext{
1 Veg. també els documents transcrits per Carreres Zacarés (1925: 40-46), on aquestes festes taurines reben el nom de «jochs». Uns anys abans, en la Crònica de Ramon Muntaner, es fa referència a la festes de toros que tingueren lloc a Saragossa, l'any 1328, per la coronació d'Alfons III (cf. DECat, VIII, 614).

2 Per a un panorama general i sintètic de les crítiques antitaurines als segles XVI, XVII i XVIII, veg. Guillaume-Alonso (1999) i Merle (1999). També els col-loquis valencians del s. XVIII solen mostrar-se crítics amb els toros (veg. Martí, e. p.).

3 Sobre aquests tres col-loquis veg. Martí (e. p.).
} 
$\mathrm{Al}$ segle XIX, cal comptar també amb la presència dels toros en la premsa satírica i en el teatre d'intenció popular. Així, en El Mole, 1855, núm. 25, p. 12-16, s'inclou la crònica detallada de tres corregudes de toros celebrades a València; igualment, en el periòdic El Bou solt (1877), dirigit per Constantí Llombart, hom pot llegir la crònica de dues corregudes de toros (p. 225-228, 253-259). Quant al teatre, podem citar l'obra d'Eduard Escalante Un torero d'estopa, estrenada el 27 de març de 1872, ${ }^{4}$ i la d'Estanislao Máñez Bous sinse pa (València, Casa de Beneficència, 1888). ${ }^{5}$

L'objectiu del present article és estudiar la història d'alguns mots relacionats amb els toros o bous, prenent com a punt de partida aquests textos dels segles XVIII i XIX, fent, així mateix, referència a altres fonts contemporànies, anteriors i posteriors, amb la intenció d'aportar noves dades històriques o complementar la informació coneguda; al mateix temps, proporcionem nova documentació així com algunes dades dialectals no contemplades en els diccionaris històrics. Comprovem algunes relacions lèxiques, dins l'àmbit taurí $\mathrm{i}$ ramader, amb el lèxic hispànic, castellà i aragonés, juntament amb la capacitat creativa de la nostra llengua.

2. toro, toret / bou, bouet. Segons indica Coromines (DECat, VIII, 614$615)$, toro (< ll. TAURU) és l'«únic nom antic d'aquest animal en la nostra llengua», el qual ha continuat tenint un «ús vigorós» en l'Edat Moderna, i avui «és l'única forma que ha restat vàlida (...) en tot el domini i en totes les esferes de la llengua», i citant Josep Giner, afegeix «que és l'única valenciana, a penes cal dir-ho». ${ }^{6}$ Per la seua part, bou (<11. BÖVE) en català, «almenys en el Nord del domini, es limita estrictament a l'animal mascle però capat, i a partir dels tres anys (...), però a les regions del Migdia sobretot, també és normal que s'apliqui al toro, especialment en terres valencianes i mallorquines» (DECat, II, $183) .^{7}$ Però el $D E C a t$ no aporta més informació cronològica ni documental per completar la història d'aquests mots en la nostra llengua. Trobem la primera referència del mot bou aplicat a l'animal que protagonitza la festa taurina en una carta dels jurats de València als representants de la ciutat en la cort reial, datada el 5 de gener de 1399, on es refereixen els actes festius prevists per «la nativitat del fill del primogènit e nét de nostre rey e senyor, hereter esdevenidor en lo regne de Sicília». D'aquests actes són exclosos els jocs de bous, per l'excessiva afluència humana que comporten: «E que a pus o altres actes a present no sia procehir, com fer juntes o altres jochs de bous induesquen gran ajustament de gents» (Rubio Vela 1998-2003: I, 305).

4 La citem a partir de les Obres completes d'Escalante (vol. I, p. 571-604).

5 Citem a partir de la segona edició en El Cuento del Dumenche, núm. 230, 1918.

6 Giner (1934, veg. en 1998: 334-335) contraposava en dues llistes els mots més usats «en el parlar occidental i en llengua antiga (occidental en lèxic)» als mots «del català literari de Barcelona»; així, en la primera llista col-locava tor, toro, i en la segona brau.

I a continuació afegeix que bou «amb caràcter lax, s'usa col-loquialment com a substitut total de toro, especialment en terres valencianes i mallorquines». Aquesta afirmació, però, no sembla adir-se amb el que el mateix autor diu s. v. toro sobre la presència de toro en valencià com a forma única, si bé es podria interpretar que en aquest cas estava pensant més aviat en el caràcter tradicional de toro, enfront del més recent i dialectal brau, com pensem que ho volia indicar Giner. 
A partir del segle XV alternen toro i bou en els textos valencians que fan referència a jocs i festes taurines. Vegem alguns exemples de bou del s. XV, en alguns dels quals se'n pot apreciar explícitament la sinonímia amb toro: «Al senyor rey és plaent que digmenge primervinent li sia feta festa de córrer bous, e no y podem contradir, car los seus prechs nos són manament[s], per què-ns cové complaure a la sua reyal volentat. E com hajam entés que vós hajats aquí thoros abtes a tal festa, per ço, us pregam affectuosament que ls nos venats o.ls nos prestets» (carta dels jurats de València a Antoni Garí, carnicer de Sueca, 14-VII-1417) (Rubio Vela 1998-2003: II, 139), «lo dit Consell provehí que, per reverència del senyor rey, qui-ls ne havia amprats, fossen acaniçats aquells bous que serà vist als honorables jurats per la forma que a aquells parrà» (14-VII-1417) (Carreres Zacarés 1925: 49), «los quals bous e toros foren correguts e acarniçats per los honorables jurats de la dita ciutat en lo Mercat de la ciutat dessús dita, lo jorn de la festa de Sent Johan en l'any MCCCCXXXXI» (id.), «Córer bous. Diumenge a IIII de march [1459], (...) en lo Mercat de València, a la part dels lancés, jugaren bous, hon fonch lo senyor rey e senyora reyna e molt gran multitut de gents (...). Lo diluns aprés meteren hun toro al[s] leons, e estech tot lo dia, que-ls leons no.l mataren. E lo dimarts aprés fonch més hun juheu. (...) Enaxí que fonch tirat lo dit juheu, e lo bou fonch soltat» (Rodrigo 2011: 264-265).

Fora del País Valencià, trobem bou per primera vegada, en relació a les festes taurines, al darrer quart del s. XV, a Lleida, quan uns estudiants, de part del rector de l'Estudi, demanaren llicència als paers de la ciutat per córrer bous: «... que a ells eren venguts certs stodiants de part de l'honorable mossèn Miracle, rector de l'Studi, per pregar a ells los donarien licència de córrer bous en la plaça, que ells se haurien bous, mas que-ls fos plasent los fesen fer les barreres, axí que-ls plàcie dar-los-hi consell. Acordaren e deliberaren que en lo nom de Déu los puxen córrer lo dia de l'Acensió e que la Ciutat los face les barreres» (3-V-1475) (CICA - Estudi III, p. 162, 1. 27), i és freqüent en uns processos judicials lleidatans del segle XVI, on bou apareix 17 vegades, i toro tan sols dues. Farreny (2004: 460) crida l'atenció sobre aquest fet, especialment sobre la sinonímia palesa entre bou i toro en aquests textos i sobre la festa de córrer bous, «circumscrita només a les terres valencianes al DECat, s. v. córrer, [la qual] s'hauria d'ampliar amb la de les terres ponentines».

A Barcelona, documentem, a mitjan segle XVI, el mot bou referit a les festes taurines, també amb el verb córrer: «Diumenge, XXIIII [maig 1554]. En aquest die, aprés lo migjorn, per lo il-lustre senyor marquès de Tariffa, loctinent y capità general de sa magestat, y per molts cavallés de la present ciutat, foren fetes y corregudes canyes y bous, a hon concurregué grandíssima gent, y los senyors deputats miraren ab los oÿdors de comptes en dues belles finestres en lo mig del Born, que logaren» (Sans i Travé 1994-2007, II: 50). ${ }^{8}$

Anys més tard, en el Calaix de Sastre del Baró de Maldà la forma habitual és toro, per referència a l'animal brau que protagonitza la corrida de toros (III, 51, 201, 209; VI, 88, 131, 137, 253; VII, 51, etc.). Rafael d'Amat, que desapro-

8 Encara que la resta de casos que apareixen referències a curses de braus a Barcelona en els Dietaris de la Generalitat de Catalunya (1411-1713) sempre es fa servir el mot toro. 
va de forma contundent les corrides de toros, celebrades seguint uns models importats, de procedència castellana, les diferencia del tradicional i popular correbou català: «La tant decantada corrida de toros ha sigut més prest correbou, segons ditxo dels vigatans, que hi són molt aficionats, com també los de Figueres, Ripoll, etc.» (VI, 262), perquè, d'acord amb els cànons reglamentats, ha resultat molt dolenta; i en un altre lloc afirma que correbous és el nom tradicional català per referir-se als jocs amb els toros: «Bon dia i bon matí i tarda que ha sigut per los aficionats i aficionades a veure la corrida de toros, avui primer dia, com tot ja nota lo «Diari» estampat d'est dia 16 de setembre; i que entre tants i tantes jo no els hi faré gens de nosa, no sent delirant per veure tals corrides de toros, o correbous, que es diu en català» (VI, 117). ${ }^{9}$

En l'obra del Baró de Maldà es troba també el substantiu brau, com a sinònim de toro: «Dia 13 d'agost [1804]. En esta tarda, a set hores, s'ha donat fi a l'última corrida de toros, i era tutti li mundi la gent que anava entrant a Barcelona pel portal de Mar, ab molta silla volant, birlotxes, tartanes, etc., que tot s'haurà llogat en esta tarda per veure córrer los braus, cavalls i torejadors» (VII, 50). En el DIEC brau 'mascle adult no castrat de l'espècie bovina', i '(emprat abusivament) vedell de més d'un any'. En el DCVB brau 'mascle de l'espècie bovina no castrat i d'edat de més d'un any', doc. Atlàntida de Verdaguer, i en femení brava 'femella de l'espècie bovina des que deixa d'ésser vedella fins que cria', doc. 1896 Massó. Coromines (DECat, II, 207-208; VIII, 615) afirma que en català, a diferència de l'occità, la substantivació de brau, com a sinònim de toro, «no ha estat mai cosa general, ni tampoc fou gaire antiga» (com el $D C V B$, no el doc. fins l'Atlàntida), i «no s'ha fixat com a substitut habitual de toro més que en sectors poc extensos del mall. i ross». ${ }^{10}$ Tanmateix, el $D A g$ (I, 279) recull documentació de brau 'bou, toro' dels segles XVI i XVII. En els diccionaris catalans del s. XIX figura com a sinònim de vedell: Belv. brau «Bou petit. Becerro. Iuvencus», Labèrnia (1839-40) brau «Bou petit de un any. Becerro. Vitulus, i», Ferrer (1839) Brau «Vedell. Becerro», D. y M. (1847) Brau. "Vedell de 1 any. Becerro», Saura (1878) brau «lo bou petit de un any. Becerro»; ${ }^{11}$ en els diccionaris mallorquins i menorquins del s. XIX es refereix al toro (Febrer i Cardona 2001, Figuera 1840, Amengual 1858).

Rafael d'Amat fa servir, així mateix, el castellanisme novillo: «en lo costat de la iglésia i convent de Santa Mònica (...) s'han posat uns pals com bigues (...), que formaran círcol per plaçar-s'hi cuant antes corrida de novillos, los que se diu vindran de Tortosa» (I, 61), «En la mateixa tarda hi hagué corrida de toros i, en la tarda següent, corrida de novillos» (III, 201), «s' ha començada en esta tarda, en lo toril, la bàrbara diversió de corrida de novillos, que a estos

9 La referència del Baró de Maldà avança la documentació del mot correbou, per relació al $D C V B$ i al DECat. En el DCVB corre-bou 'corregudes de bous pels carrers i places' (Olot, Vic, Cardona), 1. ' doc. 1908; en el DECat (II, 963) correbou, doc. 1887; en el DAg (II, 285) correbou 'corrida de becerros por las calles' (Vic).

10 Afegeix que «sembla haver sempre tingut un poc més d'extensió (així ja Lab., 1839) en el sentit 'toro jove, fins a un any'.»

11 Igualment, en occità brau és el 'taureau' (Levy, 1991), però també (brau, brava) el 'taureau, génisse jeunes’ (cf. Alibert, 2002), ‘jeune boeuf’ (Lespy-Raymond, 1970). 
seguiran, qui sap, los toros. Per lo que los catalans s'han tornat castellans per lo que molts s'hi aficionen» (VII, 25). En la memòria de despeses per les festes celebrades per l'entrada a València d'Alfons el Magnànim, l'any 1427, i en les que es feren en honor de l'infant Pere de Portugal (1429), llegim el plural novellos: «E munten les reebudes que posats haver fetes dels preus dels bous o toros qui voren venuts e altres toros e novellos qui foren tallats e venuts a menut en les carniceries de la dita ciutat e dels cuyts de aquells, XXXVII liures, VIIII solidos, VIII diners», «En lo qual compte munten les dates que havets fetes, és saber, en compres de thoros novellos (...)» (Carreres Zacarés 1925: 108, 111), ${ }^{12}$ que deu ser una adaptació de l'arag. antic noviello. ${ }^{13}$

Els diccionaris catalans dels segles XVII, XVIII i XIX generalment diferencien entre toro i bou, encara que en alguns del s. XIX s'observa un ús extensiu de bou. En Font (1637): bou «Bos, bovis», toro «Taurus, i»; en Torra (1653): bou o vaca. «Bos, bovis. Bou corb. Bos camurus. (...) Bou indomat. Bos gregarius, armentarius, armentalis, iniugis. Bou o toro de Guinea. Rhinóceros, otis. Bou de tremontana. Urus, i. Bou cabró. Hircobos. Bou cerver. Tarandus, i. Bou salvatje. Bison, tis. Bonasus, i. Bou de carreta o jou.$^{14}$ Bos

12 Cf. les vars. novellada (cast. novillada) i noveller (cast. novillero), recollides per Saura (1878). Uns anys abans, Labèrnia (1839-40), en l'entrada bou, incloïa «lo novell y no domat. Novillo. Juvencus, i». En Rovira i Virgili (1919) novell 'novillo', i en Bulbena (1919) bou novell 'novillo'. González (1996: 33) proposa el terme toro novell o, simplement, novell per referir-se als animals entre dos i quatre anys, i afegeix que «el toro novell de menys de tres anys es coneix com bravatell».

13 També en cast. antic noviello 'novillo' (cf. CORDE), si bé en el sufix -iello (<-ĔLLUM) la conservació del diftong ie és pròpia de l'aragonés, mentre que en castellà es reduí en data primerenca a $i$ (cf. Nagore, 2003: 121). Es troba cuero de noviello en documents aragonesos del s. XV (Sesma, Líbano 1982: 267), en un document de Tudela de 1362 llegim «de l'alcait de Sanchavarqua por venta de los noviellos que de su part le cayo de la cavalgada en XXX 1., XXX s.» (Ongay 1997: 44), en un albarà de Terol de 1397: «Manifiesto sea a todos hombres como yo, Pero Just, vecino de Villarquemado, aldea de la ciudad de Teruel (...), atorgo aver ovido e recebido de vos, Don Pasqual de Maenza, síndico et procurador de la dicha ciudat, (...) once florines de oro buenos de Aragón, por razón e precio de un noviello hosco que (...) comprastes para correr en la dita ciudat, por las alegrías que en aquella se facen (...) por el senyor rey Don Martín...» (J. Caruana: «Un precedente de la vaquilla del àngel», en línia http://www.portalvaquillero.es/web/index. php?option=com_content\&task=section\&id=17\&Itemid=116).

${ }_{14}$ Cf. «acaminaben molt espai, com si foren bous de carreta» (El Mole 1837: I, 163), «qu.ell té la forsa que-m falta / pa moure a un bou de carreta!» (Balader: Misèria y compañia, València, 1872, p. 24), «una chica morena, groseta, (...) desgarbà com ella a soles, perquè el seu cos se li pareix a un espigó y el seu caminar al de un bou (però de carreta)» (El Cullerot 29, 1897, 3). Hom es refereix també a aquests animals amb els noms de bou de faena, bou de llaurar, bou (i vaca) de llaurada i bou de treball en els textos valencians dels segles XVII, XVIII i XX: «si serà bestiar gros, exceptat bous de faena o cavalcadures» (a. 1630) (Diaz Manteca 1983: 51), «en temps de llaurades puguen los bovers tallar per a els bous de llaurada una rama que atra» (a. 1738) (Barreda 1996-97: 466), «si ninguna bèstia o bou de llaurada seran atrobats en heretats de altri» (Guinot 2006: 319), «Rúbrica de les vaques de llaurada» (id.), «Rúbrica de les bèsties y bous de treball» (id.), bou de llaurar (a. 1690) (Pérez 1995: 100). En els Establiments (1576-1759) de Catí es distingeixen les «bèsties de treball, bous y vaques de llaurada», que els veïns podien posar en els bovalars, de les «bèsties braves», que no les hi podien posar (Guinot 2006: 335). 
iugalis, iugatorius, iugis», toro «Taurus, i»; en Lacavalleria (1696): bou «Animal. Hic Bos, bovis. (...) Bou de arada (...). Bou de carreta (...). Bou de ramat (...). Bou de engreixar (...). Bou salvatje. Hic Bubalus, li. Bos ferus. Bos silvester. Bos silvaticus», toro «Animal. Hic Taurus, i»; en el Prontuario trilingüe (1771: 103) de Josep Broch: bou «Buey. Boeuf», toro «Toro. Taureau»; en Belv: bou «Buey. Bos. Bou jove, encara no domat. Novillo. Juvencus. Bou mener. Cabestro, manso. Sectarius bos. Dux gregis», toro «Toro. Taurus»; en Labèrnia (1839-40): bou és el «toro capat y domesticat per a llaurar, tirar lo carro, etc. Buey. Bos, vis», i distingeix, entre altres, el bou maliciós «Lo que és astut y taymat. Marrajo. Callidus bos», i el bou feréstech o salvatge, sinònim aquest de toro,$^{15}$ que defineix com «animal quadrúpedo gran, que brama, de membres fornits y nirviosos (...) És animal ferós, principalment irritat, encara que capat y amansit se domestica, y serveix molt per als traballs del camp, y alashoras se diu bou». Ferrer (1839) defineix bou com a «Buey. Toro», i dins d'aquest destria «Bou jove. Novillo. Bou maliciós. Marrajo. Bou mener. Cabestro. Bou vell. Cotral. Bou engrexad. Cebón», i dins de toro, el «Toro ferésteg. Uro». Igualment, en Saura (1878) bou és el «toro capat y domesticat. Buey», però també el «no capat. Toro», així com el «jove y no domat. Novillo» i el «feréstech. Uro».

Les definicions de Labèrnia i de Ferrer mostren un ús extensiu de bou al Principat, referit no únicament al mascle adult castrat. De fet, en Pou (1580, f. 25) es troba ja un ús extensiu d'aquest mot, en l'apartat «Dels bous», on s'inclouen, a més del bou, la vaca, el vedell i la vedella. Segons Delgado Ruiz (1994-95: 79), a Catalunya, mentre que el brau o toro és l'animal que protagonitza les corregudes convencionals (el toro bravo castellà), el mot bou serveix per designar indistintament la totalitat dels bòvids, castrats o no, ${ }^{16}$ «de manera que las fiestas tradicionales con toros que no están gubernamentalmente reglamentadas son llamadas corre-bous». González (1996: 32), per la seua part, afirma que «en el llenguatge comú, el mot bou s'utilitza més aviat per referir-se a l'animal castrat, mentre que toro s'identifica amb el no castrat», però «el llenguatge tauromàquic català (...) manté viva la sinonímia entre bou i toro. Bous, en plural, és sinònim de festa popular amb bous o, fins i tot, de corrida». En la nostra societat el bou és el boví més lligat tradicionalment a l'home, fet servir en els treballs agrícoles, com a bèstia de càrrega i per a l'obtenció de carn. Això degué facilitar l'ús extensiu del mot que el designa, el qual en alguns dialectes, com en el val., ha acabat substituint toro de l'ús popular recent. ${ }^{17} \mathrm{Cal}$ tenir en compte que l'ús extensiu de bou creà una relació desequilibrada, puix si bou

15 Enregistra també una variant tor. Encara que tor compta amb alguna presència antiga en català, prompte es va antiquar (cf. DCVB; DECat, VIII, 614), i al temps de Labèrnia deu entendre's més aviat com un intent d'adaptació de toro.

16 En val. té lloc també l'ús extensiu de bou. L'ús ampli de boeuf 'mammifère ruminant de la famille des bovidés (bœuf, vache, taureau, buffle, yack, bison, etc.)' es coneix també en francés (TLFi).

17 No creiem, com diu Saumade (2006: 167), que l'ús del mot bou en les corregudes populars de Catalunya i el País Valencià «para designar lo que en realidad es un auténtico toro bravo» s'haja d'interpretar en el seu origen per «la tendencia a parodiar el modelo nacional», ja que, com 
podia usar-se en lloc de toro, la substitució no era possible a la inversa, la qual cosa afavoriria l'extensió del primer en detriment del segon. El principi d'economia pogué resoldre el polimorfisme toro / bou, per relació a l'animal brau, a favor de la forma que comptava amb un ús més ampli, com ha ocorrregut en valencià. El context solucionaria les possibles ambigüitats, i, en cas de dubte, si aquest no era prou aclaridor, hom podia recórrer als complements, com bou de carreta o bou de llaurada, que hem vist més amunt, per precisar les característiques de l'animal.

Si consultem els diccionaris valencians dels segles XVIII i XIX, veiem que Carles Ros (1764) manté el sentit etimològic de bou «buey, el toro castrado»; igualment, Escrig (1851) diferencia entre el bou «buey (cuadrúpedo)» i el toro o tor «toro (cuadrúpedo)». En canvi, EscLl i MGad ja inclouen el doble sentit de bou 'buey: toro castrado para las labores del campo, carretería, etc.' i 'toro', juntament amb toro i tor. En EscLl també bou feréstech o salvage «toro», ${ }^{18}$ bou malicciós «Marrajo», bou mener «lo mismo que bou esqueller», bou per a caçar perdius «buey de caza», bou vell per a la matança «cotral, cutral». ${ }^{19}$

En els textos valencians, bou i toro, referits a l'animal que protagonitza les festes taurines, continuen als segles XVI i XVII, com ho podem comprovar en els dietaris i cròniques de l'època (Jeroni Sòria, Porcar, Aierdi, Libre de memòries, Libre de Antiquitats), així com en el Manual de Consells de la ciutat de València, amb percentatges diferents segons els textos. En els documents que hem consultat del Manual de Consells, en les festes taurines de maig de 1691 (A-222, f. 460-461) i en les d'agost de 1692 (A-224, f. 125-129) apareixen toros i bous; en les del 4 i 5 juliol de 1622 (A-149) i en les del 29 d'abril de 1625 (A-149), només bous, com també en les celebrades a la plaça del Mercat de València el 10 de setembre de 1668 (f. 244-246): bou, bous, festa dels bous, corro de bous, crida de bous. En canvi, en els toros reals que es van fer

veiem, l'ús extensiu de bou en cat. és molt més antic que la difusió de la lidia homologada d'origen espanyol.

18 En MGad: bou feréstech, fréstech o salvage.

19 Voldríem referir-nos a una accepció metafòrica de bou no enregistrada en els diccionaris, que trobem en alguns textos valencians de principis del s. XX. Es tracta del bou de foc, o simplement bou o bouet, que designava un artefacte pirotècnic: «lo bon cueter Ponent / la corda ajusta en seguida, / y les peses y armament / de què deurà ser bastida. / Ha de tindre deu galeres / de a cuaranta-huit, y, és clar, / partició de a cinch; llaujeres / eixides al comensar, / vistoses y joganeres; / y a l'estil de l'antigor, / murciana ben rebonica, / paseante en rodador / y un cuet arrastrador / que als chorros no.n deixe mica. / Com a terme (...) / una traca en cuets borratjos. / (...) Y abans d'ella un bou de foch / no ha de fer falta tampoch, / però, com tot en Espanya, / també asò ha sufrit retoch, / y el bou ja no és bou, és canya» (Las Provincias. Almanaque 1902, p. 171-172), en la descripció detallada descripció d'una corda, «Ningú ha conegut que ha estat / la culpa del desafiu / en una que-ls ha mirat / de darrere un enfilat, / dende a hon coqueteja y riu, / fent més mal que el bou o canya / que ompli de foch el carrer, / perquè may és cosa extranya / que el foch d'uns ulls vinga a fer / la cremà que més nos danya» (id., 173). S'encenia en la cordà de Paterna, a finals del s. XIX: «Quan ningú se ho esperava, allà te venia Rampa, el fill més xiquet del coeter, que a la punta d'una canya portava un «bouet», o siga, una «peça» amb dos xorros de xispes que anava derramant coets encesos, $\mathrm{i}(. .$.$) se ficava entre la moltitud ell i la seua càrrega de dimonis encesos»$ (Ernest del Molí: Una llocà, s. 1., s. a., pp. 12-13). 
l'any 1659, per festejar la canonització de Tomàs de Villanueva, sempre toro: «que en lo dia de nou de maig, en la plaça de Predicadors, es facen toros reals (...), y en lo dia de vint-y-quatre en dita plaça es tornen a córrer toros reals» (A-190, f. 476v), «y manaren que-s correguesen dos toros» (f. 556r), «la festa dels toros» (f. 556v), «dins lo corro de toros» (f. 557r). ${ }^{20}$ En el Dietari de Porcar es nota, però, una clara preferència per bou: s'hi compten 131 casos de bou (bous), aplicats a l'animal brau que es corre o toreja, i tan sols 17 de toro (toros).

Al segle XVIII, en els dos col-loquis de Ros que descriuen corregudes de toros reals en la plaça de toros, el Romanç nou (1738) i la Nova y gustosa relació (1741), apareix habitualment el mot toro, amb un sol cas de bous en el segon text (p. 3). ${ }^{21}$ En canvi, en el Romanç entretengut sobre la correguda de bous en sarauuells (1752), l'únic col-loqui que descriu una correguda popular en el carrer, encara que de bous figurats, representats per homes, a causa de la prohibició que pesava, des de 1748, sobre els bous en les festes de carrer, hom fa servir habitualment bou, amb un sol cas de toro, precisament quan hom compara aquesta festa amb els toros reals: «que va acudir / més gent que als toros reals» (75-76, ed. Torres Navarrete 1995). Ros, per tant, en aquests textos sembla preferir el terme toro per a les corregudes més formals i convencionals, i bou per a les més populars, que tenien lloc als carrers, ${ }^{22}$ seguint potser alguna tendència lingüística popular. Per últim, en el Romans nou de la correguda de baques y bedells, feta en un camp, prop de la Zaidia, tocant als murs de València, de caràcter més informal que els toros reals dels dos primers romanços, però no tant popular com els bous de carrer, alternen bou (3 casos), bouet ( 2 casos), toro ( 2 casos), toret ( 3 casos), amb les formes diminutives referides més específicament als vedells.

Quant als altres col-loquis taurins valencians dels segles XVIII i XIX, en l'anònim Coloqui entre dos llauradors (1748), que descriu també una correguda de toros reals (v. 237), la forma habitual és toro (pàssim), i el sinònim bou només hi apareix dues vegades (títol i v. 74); en el Coloqui dels carafals alternen toros ( 3 casos) i bous (4 casos), i en la Corrida de toros (1831) predomina bou, i toro només hi apareix en una ocasió: «correguda de toros» (v. 8).

En efecte, en els textos valencians del s. XIX es manté el mot toro, ${ }^{23}$ juntament amb bou, si bé hom pot observar, en general, un major ús del segon. En

20 Els toros reals (toros reales en cast.) rebien aquest nom perquè procedien de la ramaderia que originàriament tenia la família reial, des de temps de Carles I, per les riberes del Jarama i del Manzanares, famosa per la seua bravesa (cf. Leralta, 2002: 165-168).

21 L'espectacle taurí en el Romanç nou de 1738 és anomenat correguda de toros (p. 3), correguda de toros reals (p. 1) o simplement correguda (p. 1), i l'acció, córrer toros (p. 2); en la Nova y gustosa relació es fa servir l'expressió festa de toros (p. 3).

22 En algun altre text, però, Ros també fa servir bous per referència a les corregudes de bous reals: «aprés dels bous reals, / que els més anys fan en València» (Proseguix lo assumpt dels jochs dels gichs especials, p. 3 ).

${ }_{23}$ Es troba en textos i autors ben populars, encara a la segona meitat del XIX, ex. «Estaria yo bonico / si me ixqueren en el cap [les banyes]... / Entonses sí que.1 señor / Achuntament popular / me tancaria en la plasa / dels toros... ben formigat» (Castillo: El diable en capa de sant, València, 1870, p. 19), «el serdo pareix un toro, / y les olives, simbombes» (Palanca: Secanistes de Bixquert, 
aquest sentit, Josep Bodria (1842-1912), parlant dels bous de carrer a la ciutat de València, encara que era conscient de la diferència originària entre toro i bou, afirmava que la segona era l'única forma popular: «Era també de caixó en alguns carrers, después dels dos dies de festes, córrer bous (per més qu·eren toros, lo vulgo sempre ha dit bous)»(Festes de carrer, València, 1906, pp. 13-14) ${ }^{24}$ Però, de fet, en els textos populars valencians d'aquesta època no és absent el substantiu toro, sovint, però no exclusivament, unit a les corregudes convencionals, en places tancades destinades específicament a aquest espectacle i on el públic participa només com a espectador, les places de toros, i no és descartable que en aquest context pogués rebre, sobretot a la segona meitat del s. XIX, el reforçament de les corridas de toros institucionalitzades d'origen castellà. ${ }^{25}$

Xàtiva, 1867: 53), per la seua grandària; «Yo compare els partits al[s] toros pares de les vacaes, que riñen per qui quedarà amo del cotarro» (El Mole, 1870, p. 22), «pot demanar informes (...) al director d'un periòdic de tres puntes, sobre les herbes que té el novillo, y en seguritat li diran que no solament és marraix, sinó que té la mala intensió de un toro esquerrer» (El Bou, Elx, 1885, núm. 29, 16, p. 3), «és toret de chènit, y no ha-y qui el aguante cuant li donen el cos» (id., núm. 29, p. 2), «Yo li claví, en Almusafes, / a un toro dels braus, navarro, / un par a la media vuelta» (La Contumènsia de Valènsia, 1893, núm. 2, p. 3), «sols que a Rafael may l'agarraben els bous, y a Romero l'estan agarrant tots els dies, sense consecuènsies, por supuesto, perquè la cara de Romero pareix cara de picaor de toros, que peguen cada minut una tamborinà mascle y s'alsen de terra com si tal cosa» (La Moma, València, 1886, suplement al núm. 6, p. 1).

24 La popularitat de bou en val. amb el sentit de 'toro' explica els sentits del der. bouero que, amb el sentit de 'torero' i 'aficionat als bous, a les corregudes de bous', documentem al s. XIX i principis del XX: «Com el número que ve serà a benefisi del segon espà de la cuadrella de bohueros, o siga, el administraor de este periòdic» (El Bou, 16, 1885, p. 1), jugant amb el nom del periòdic El Bou d'Elx; «Per una part la guitarra, / y per l'atra el dolçayner. / (...) Lo que toca el pipantero, / en la plaça l'ha vist yo, / y els juahors y els boueros / tots estan ahí al cantó» (Troços y mosos, València, 1906, p. 10), en les festes de Sen Gayatano de Famorca. Cf. en el castellà d'un informant catalanoparlant de Massamagrell: «Nunca he sido quinto ni na(da), o sea que lass fiestas que yo he tenido ha sido con los amigos de- dee- de la infancia, o amigos por ejemplo enn- Puzol de- del instituto, que- que son mucho más boueros, que dicen ellos, que en mi pueblo» (Gómez Molina, 2005: 349). En el DCVB, el DECat (II, 184) i el DAg (I, 273) només bover (bouer, boer) 'pastor de bous; qui guarda bous', així com 'tripulant d'una barca del bou' $(D C V B)$, 'qui llaura amb un parell de bous' (Pla del Llobregat) (DAg), i nom d'un estel: estel bouer (o bover) i d'un caragol: caragol bover (o boer). Aplicat a un pastor de bous, es doc. en val. bouer al s. XVII, en les Ordinacions d'Albalat dels Sorells: «que ningun bouer siga gosat de entrar en camp de altri, ni per sendes, màrgens ni regadores, los bous, so[t]s pena de vint reals» (Rodrigo, 2010: 315), probablement amb el sentit de 'ramader de toros braus', llegim: «Vicent de Sagra, bouero professional, vertader dominador del[s] bous braus, que de regrés a casa seua després de córrer el seu ramat per la Vall de Pego, viatjava al costat del bou anomenat per uns el «Roget» i pels altres el «Paraigüero», tenint els guanys a dintre un saquet penjat al topo d'aquell temible animal» (Cardona Ivars: 1986: 127). Els boueros eren també a València els encarregats de conduir els bous en la pesca del bou: «Blasco (...) féu allí moltes amistats. El coneixien els boueros, que guien, montats damunt la testa, amb la parella de bous, les grans barques de peixca que estan arrenglerades en la platja durant les temporades sense treball» (Just: Blasco Ibáñez i València, València, 1929, p. 78).

25 Recordem que la moderna plaça de toros de València va ser inaugurada en agost de 1851, amb toros i toreros castellans i andalusos. 
Deu haver-hi interferència castellana en algunes locucions formades sobre comparacions amb referents castellans, com bramar com un toro de Gaviria: «però com sinse ducte té notísies de que-l calabre també vol vestir-se de soldat, caballers, està que brama com un toro de Gaviria» (L'ametrallaora carlista, 5, 1871, p. 2), en més verí i més coratge que té un toro de Veraguas: «Sinse por, damunt les bèsties, / me tire, sego de ràbia, / en més verí y més corache / que té un toro de Veraguas» (Escalante i Feo: Cada u de son temple, València, 1890, p. 43), tenir més corretja que un toro del Colmenar: «iNi que tingues més correcha I qu·un toro del Colmenar!» (Virosque: El sant dels tres, València, 1919, p. 7).

En les cròniques taurines d'El Mole de 1855, que descriuen uns espectacles convencionals, amb toreros forasters, entre els quals destaca el famós Cúchares, apareix sempre toro, amb l'única excepció de l'expressió bous, o vaques o gallines en sabates, per referència a uns toros gens braus: «Terser dia. (...) De nou toros. Hagué dos tal cual, y set empeltats de bous, o vaques o gallines en sabates. El no haber ocurrit res que dir és lo únic de particular que ha oferit esta tersera estasió boual» (núm. 25, p. 16). ${ }^{26}$ L'expressió popular bous, $i$ vaques $i$ gallines en sabates és ben coneguda en valencià, ex. "Allà vénen bous y vaques, / y gallines en sabates, / gallets en carapuchets / y una lloca en tres pollets» (Alberola: L'amo y señor, València, 1927, p. 68), formant part d'una cançó o corranda popular, que diu Contaralles, molt afeccionat a aquestes coses; «-A la plasa, / sí, a torechar bous y vaques / de Visantet el del Puig. / -Y gallines en sabates. / -Pos tenen unes fitores / com unes forques de batre» (Alfonso: El propi amor, València, 1926, p. 9), insinuant, a partir de la relació amb les gallines, que els animals resulten mansos o poc braus. En les cròniques taurines d'El Bou solt (1877) predomina bou, però també s'hi registra toro. En el sainet d'Escalante Un torero d'estopa la forma més usual és bou, però toro s'hi documenta diverses vegades, i per últim, en el sainet de Máñez Bous sinse pa, sempre bou.

A banda del seu ús com a veu independent, en els textos valencians d'intenció popular dels segles XVIII i XIX no és gens rar llegir locucions formades sobre el mot toro, les quals semblen indicar que no deixava de ser conegut popularment. En alguns casos la rima de toro amb moro podria confirmar el caràcter obert de la $o$ de toro, $\mathrm{i}$, per tant, ser una prova favorable de la seua genuïnitat i diferenciació respecte al cast. toro, mantinguda encara a la segona

26 Destaquem també en aquest text l'adj. boual 'propi dels bous', per referència al tercer dia de corregudes de bous. En el $D C V B$ s. v. boual hom remet a boval, on, en efecte, sota el lema doble boval o boal, la primera accepció és l'adj. 'propi de bous', garrover boval, nap boal, sense documentació. La variant amb $u$, boual, només la documenta aquest diccionari, com a substantiu ('lloc on antigament donaven la palla als bous, quan encara no hi havia estables', Men.), en un text menorquí modern, i en l'apartat de la fonètica només recull les formes amb labial (boval, bobal) i la variant vocàlica bual; el DECat (II, 184) es limita a reproduir l'exemple menorquí de boual del $D C V B$; igualment, en el $D A g$ (I, 272) boual 'estable de bous'. En canvi, segons els diccionaris valencians del s. XIX, l'adj. boual era també conegut en valencià. Així, en Escrig (1851) llegim: bobal. adj. V. bohual adj. i bohual adj. «Boyal», i el substantiu bohualar V. bobalar; i després, de forma semblant, en EscLl i MGad. La forma boual del text d'El Mole confirma, doncs, la vigència d'aquest adjectiu en el val. del s. XIX. 
meitat del segle XIX en una àrea valenciana més extensa que l'actual, ${ }^{27}$ però també podria ser una falsa rima, motivada per l'escassessa de mots en -oro fora d'aquests. Siga com siga, entre els valencians, almenys entre els lletraferits, no es perdé la percepció lingüística que toro era la manera més apropiada de referir-se a l'animal brau que es torejava a la plaça. Així, l'any 1931, en la revista Pensat i fet (p. 26), hom es referia a les «corregudes de tòros» (amb accent obert sobre la «ò») que, amb motiu de la festa de les falles, s'havien de celebrar en la «plaça de bous» de València.

A les locucions que citàvem en una altra ocasió (Martí, 2012: 59-60), podem afegir-ne ara d'altres. Generalment es fan servir per a ponderar els sentiments intensos, la irritació, la fúria, la mala intenció: bufar com un toro: «-Bufant se'n va com un toro. / -Y furient com una bala» (Balader: El chiquet descuartisat, València, 1869, p. 17), bramar com si fóra un toro (lo mateix que un toro): «El tal ingeniero era / de Suchet molt estimat, / y quan lo veu sinse cames / dihuen que perdia el cap / y es pegaba tosolons / contra les parets, bramant / ayxí com si fóra un toro» (Conversasió que tingueren Saro Perrengue, guerrillero..., 1813, p. 2), «Y pués de serts malalts coneix pro y contra, / per més que bramen lo mateix qu un toro, / pa ells este piló de riu no encontra / medisina millor que la de moro» (El Dotor Cudol, 2, 1880, p. 3), rimant amb moro; bramar com un toro en la devesa: «Mariano: -Lo que yo dia, ma neboda / mos pendrà la delantera. / Guillerma: -Y tu ho dius tan satisfet? / Pos yo estic molt recoenta. / Mariano: -Yo també, mes vols que brame / com un toro en la debesa?» (Ovara: Per tres pesetes y micha, València, 1881, p. 12), enfurit com un toro: «Pos m'ha dit carantonyera, / falsa, i de quina manera! / Com un toro d'enfurit!» (Sainets il-licitans de la Restauració, Alacant, 1994, p. 284), furiós com un toro: «La brometa l'ha cremat. / Està furiós com un toro» (Huertas: El mestre de fer coloquis, 1875, BMV, ms. MG 153, p. 36), ${ }^{28}$ en més malíccia que un toro: «-Sempre parlant en malícsia. / -En més qu·un toro» (Balader: Eixarop de llarga vida, València, 1863, p. 61), posar-se com un toro 'enfurir-se molt': «Perquè des de que han puchat / als dichosos caballets, / casi sempre han estat quets; / molt poc és lo que han rodat. / (...) L'u com un toro se posa; / este brama y l'atre chilla» (Relasió y esplicasió de la falla dels cuatre cantons dels carrers de Gràsia y En Sans. Ã̃ 1906, València, p. 4), tenir (algú) més intenció que un toro 'tenir mala intenció, ser mal intencionat': «Marta: -Se n'ha·nat? Torne per dir-los / sols qu-eixa és una enredranta, / y per gust de armar un chisme / no·s chita en una semana. / Té més intensió que un toro, / y... si.t descuides, t'engancha. / Com la envecha fóra roña, / no hauria mans pa rascar-la» (Cidon: Les beates, València, 1909, p. 13-14), ${ }^{29} \mathrm{i}$ amb un altre sentit mirar la correguda

27 Actualment, el mot toro ha reculat molt en l'ús popular val., però encara es conserva en el parlar de Crevillent i Guardamar, amb o oberta (Segura, 2003: 271, 374).

28 Cf. estar més furient que un bou: «Estic més furient qu·un bou! / (...) Roseta, (...) / no es chua d'esta manera / en lo cor d'un home blanc» (Garcia Capilla: Cada ovella en sa parella, València, 1868, p. 17), «Visantet: -Si vol que fem bona lliga, / crega'm vosté y no me diga / res que tracte d'eixe punt. / (...) Chuano: -(Està més furient qu·un bou)» (Tous, Cerdà: Foch en l'era!, València, 1900, p. 31).

29 Cf. tenir més mala intenció que un bou de Xilxes: «Sí, senyor, tenen més mala intenció que un bou de Xilxes...» (Pascual Tirado: De la meua garbera, Castelló, 1935, p. 97), els de Borriol. 
dels toros des de dalt lo carafal: «-Com se coneix que faltàbem / los tertulians del Mercat, / que si no, ya haguera vist / eixe lladre consumat / qui és cadascú de esta terra... / -Una gran cosa és mirar / dels toros la correguda / des de dalt lo carafal, / com solem dir en València» (Coloqui entre el tio Bernat y Saro..., 1813, p. 2), posant en dubte la certesa de les paraules de Saro, i respirar com un toro cansat: «El senyor Roc està fet un basilisco en lo seu establiment de apanyaor de cadires de vell. (...) Respirava com un toro cansat» (Pensat i fet, 1921, 16).

3. corro 1 'plaça de toros', pot referir-se al conjunt de la plaça, incloent-hi les grades ocupades pels espectadors, i els altres espais que la componen: «Tan hermós me paregué / tot el corro que a l'instant / em figurí una pintura / de països alemans» (Coloqui entre dos llauradors, vv. 53-56), «Però anem a veure el corro, / que està fet un bobalar / de tribunals y tontillos / y de la gent popular» (Nova, 2), «Qui no vera per lo corro / als més botant y sagrant, / fets uns llinces, per si vehuen / algun senyal de cobrar» (id.); o més aviat, a l'espai o rotllana on es desenvolupa l'espectacle, ocupat pels toros, els torejadors i els cavalls: «Yo els hi declararé ara: / de el toril de la tibieza / ix una fiera molt brava, / que té per nom / (...) la Indevoció: però acaba / al punt que a este corro ix, / puix una montja li clava / la galotja de el Fervor» (Coloqui per a la festa, 142). 2 'corral situat junt a la plaça o el lloc on es corren o toregen els toros, $i$ on aquests es tanquen després i abans de l'espectacle': «em digué: «Qu-és asò, amic?, / vosté també s'ha topat / en la fiesta de los toros?» / Y yo li u vach otorgar, / perquè els toros en lo corro / poc ha que habien entrat» (Coloqui dels carafals, 3), després de la correguda. 3 Sinònim de 'festa de toros, correguda de bous': «Volguera jagants y nanos, / volguera una maixquerada, / volguera un corro de bous / y que y haguera una danza» (Coloqui per a la festa, 139).

En el DCVB corro 'corral on es tanquen els bous que s'han de córrer', doc. en l'Spill de Jaume Roig, en la Brama dels llauradors de Jaume Gassull, i en un text de 1560 procedent del Manual de Novells Ardits barceloní. Hi és qualificat de forma antiquada, però en l'apartat de la fonètica es recull en val. Pel que fa a l'etimologia, el $D C V B$ el considera pres del cast. corro id. Abans en el DAg (II, 290) corro 'redondel', doc. en Lo procés de les olives, en un Confessional valencià de 1493, així com en les referències de la Brama i del Manual que reprodueix també el $D C V B$. Quant a la definició de 'corral...' del $D C V B$, no sempre sembla correspondre als exemples que cita; per ex., la referència de l'Espill, Peirats (2010: 357) la interpreta com a 'plaça on es toreja', un sentit semblat deu tenir l'exemple de la Brama (cf. ed. Miquel i Planas, 1911, p. 350), i el del Manual de Novells Ardits («corro de toros») remet al sentit de 'festa o correguda de toros' ${ }^{30}$ Per a Coromi-

30 Aquesta no és l'única referència de corro de toros procedent de Catalunya; en trobem altres exemples dels s. XVI, XVII i primers anys del XVIII, referits també a la festa taurina: «havia determinat, per la alegria que lo present Principat sent del casament del nostre rey y senyor, de fer corro de toros y joch de canyes en la plassa del Born de la present ciutat» (a. 1560) (Sans $\mathrm{i}$ Travé 1994-2007: II, 93), «féu fer corro de toros y joc de canyes, en lo qual isqué lo dit il·lustre loctinent general y molts cavallers» (id., 94), «que los gremis que no van a la professó ni han suportat gasto fàssan invensions de foch o altars, dos dias de corro de toros y altres cosas» (a. 1701) (id., X, p. 44), «Al 17 de Novembre de 1674 se comensaren les festas de Maria Sanctíssima del 
nes (DCECH, II, 203-204; DECat, II, 948), corro «no ha estat mai pròpiament català», i es troba «en ambient específicament valencià, entorn de 1500 o poc abans», per referència a «la rotllana o rodona de la plaça de toros», i el considera un mot d'origen castellà, d'on passà al val. del s. XV, si bé no hi descarta totalment una «possible contribució mossàrab».

Vegem-ne altres exemples dels segles XVI i XVII, entre molts més que podrien citar-se, procedents també de terres valencianes, referits a l'espectacle o festa taurina, i a la plaça o espai on tenia lloc aquesta festa:

En la part documental del Ensayo de Carreres Zacarés (1925), es troben, als segles XVI i XVII, diverses referències als corros de (dels) bous que es feren en celebracions festives de la ciutat de València. La més antiga tingué lloc amb motiu de l'estada a la ciutat de Ferran el Catòlic i la seua esposa Germana de Foix, en setembre de 1507: «per lo administrador de la Lonja sien donats al magnífich en Johan de Miranda, donzell, de la thessoreria del Rm. senyor deu ducats (...) per lo preu de hun bou que li han alancegat en lo corro dels bous que.s féu al rm. senyor», «provehexen que per lo magnífich administrador de la Lonja nova sien donats a Baltasar Forés huytanta-huyt liures, dehuyt sous (...), per tres bous que li són stats morts e perduts en lo corro dels bous per les festes fetes per la senyora reyna. Ítem, L liures VIII sous per loguer o conduhiment de XXXII bous per al dit corro de dos jorns» (p. 194).

Altres exemples:

«en acabant de dinar, à de anar la enperatriz a la plasa a veure un corro de bous y goc de cayes que fan vuy per ser dia que lo prínsep cunple sos anys» (a. 1537) (ap. CICA - Liori i Requesens, Epistolaris, c. 129, 1. 26).

«féu-se (...) un corro de bous, y los cavallés jugaren a canyes» (a. 1556) (Martí 1994: I, 211).

En les Memòries de Vicent Torralba en la descripció de l'itinerari de la processó del dia de Sant Donís de 1638, s'esmenta el corro, referit segurament a l'espai on es corren o toregen els toros, situat en la plaça del Mercat de València: «Y por la calle dels Cotamallers entraren en lo Mercat y passaren per lo mitj del corro que estava fet per a els bous» (Ferrando 1995: 54).

Apareix diverses vegades en el dietari de Porcar, ex. «Dilluns, a 4 de juliol 1622, havent de haver corro de bous en lo mercat de València no-ls y hagué. Estant aguardant lo corro moltíssima gent, vingué Pere Pi, trompeta de la ciutat, y preconisà que no y havia bous. Y que axí, no-s fia lo corro, estant tot adresat lo soli del virey, ab grandíssima magestat. Y estant en lo cadafals los jutges de la Real Audiència y los deputats, féu dit Pi la crida, y axí se n'anaren» (CICA - f. 391v, 1. 12), «Bous. Dilluns, a 17 de setembre 1618, y hagué en la plaça de Predicadors corro de bous. Y a l'endemà no.ls y hagué

Patrocini [...]. Dimarts al 20 de dit mes [...] y després de vespres se feu corro de toros en la plasa de la Fira y fou bona insta y acudí gran número de gent tots los dies de moltes parts» (Barberà i Soler, 2004: 21). 
perquè plogué; encara que havien portat ya los toros al corral del corro» (id., f. $302 r$, 1. 11), on veiem com el terme corro s'aplica tant a la festa o correguda de toros, que és el sentit que documentem més sovint en aquesta època, com a l'espai on aquests es toregen.

Convé no perdre de vista l'expressió corre de toros (corra de toros), que trobem en textos del Principat del s. XVII, amb el mateix sentit que corro de toros o corro de bous 'correguda de toros': «Dilluns, a III. En aquest die hy hagué corre de toros en dita plassa per lo naximent de la sereníssima princessa, estaven en la forma del die de haïr ab moltes dames en son catafal» (a. 1602) (Sans i Travé 1994-2007: III, 416), «contenint que dimars primervinent que contarem als XXVIII del corrent mes, devant de palàcio a.y hauria corra de toros ab lo qual festín solemnisaria los anys de la reyna nostra senyora» (a. 1698) (id., IX, 976), «dimecres a 13-I-1677... en la plassa de Palàcio se feren unes festes de corre de toros... y al mars se féu altre corre de toros, y se tiraren focs...» (DECat, VIII, 615), «La Diputació féu fer corre de toros en la plaça del Born» (Miquel Parets, ap. $D A g$, II, 285) ${ }^{31}$ «I les vespres de la mateixa manera, les quals acabades, se féu gran corre de toros en la plasa Major de la fira, i tots estos officis se feren gratis per haver-o demanat la vila a la comunitat» (a. 1667) (Garganté 2011: 160), «Pel setembre de 1629, la confraria dels blanquers féu «corre de toros», a la plaça de la Blanqueria» (Carrera 1951: 444). Cal recordar també el corre de bou que es celebra en alguns llocs de Catalunya, com Cardona, al s. XIX amb bous de la llaurada, i que anteriorment es documenta amb els noms de corre de toros (a. 1667) i corro de toros (a. 1674) (Barberà i Soler, 2004).

En el DCVB corra 'correguda; cursa', que documenta precisament en els dos textos que citava el $D A g$, mot que creu procedent «probablement de l'infinitiu córrer, substantivat i interpretat com a femení a causa de la seva terminació fonètica amb -e neutra». ${ }^{32}$ La documentació dóna suport a la interpretació del $D C V B$ : En el mateix segle XVII es recull a Barcelona la forma substantivada «el córrer dels toros», referit a la festa taurina: «Dilluns, a XVII. En aquest die se féu la festa del córrer dels toros, per lo naxament del sereníssim príncep de Espanya, en la plaça del Born de la present ciutat» (a. 1629) (Sans i Travé 1994-2007: V, 302), i un poc més avant llegim: «a hont se corregueren molts toros, braus y ferosíssims, que donà gran contento a tots los qui veren la dita festa» (id.); igualment, en uns memorials de comptes del Consell de Cent de Barcelona d'abril de 1602 llegim: «la festa del torneig y corre de toros», i, amb el mateix sentit, «obres per lo catafal que-s féu en la sala de armes per a mirar lo córrer de toros» (Brú, 2004: 87).

31 El DAg en cita un segon exemple, procedent de La Veu de Montserrat (1879, 44): «dia segon de las festas agué corra de toros».

32 Coromines (DECat, II, 950) recorda també «un corre o corra substantiu en dos textos del Princ., del s. XVII o un d'ells posterior, citats pel $D A g$.», i considera que el context és insuficient «perquè puguem judicar clarament si és la corrida de toros o bé una variant d'aquest corro 'plaça de toros' amb un poc de metonímia en un d'ells». En realitat, els altres exemples que hem pogut trobar confirmen, com hem vist, que es refereix a la 'correguda de toros', significació que, a diferència del que pensava Coromines, pot tenir també la veu corro, com hem pogut comprovar en els nombrosos exemples citats més amunt. 
La construcció córrer de toros 'festa de toros, correguda de toros' es documenta ja al segle XVI. ${ }^{33}$ En una carta d'Antoni de Capmany a Vargas, transcrivint una notícia de mitjan segle XVI procedent d'un antic diari de la ciutat de Barcelona, conservat ms. en l'Ajuntament d'aquesta ciutat, es llegeix: «Lo dia de S. Joan de juny de dit any 1554 aprés dinar los (sic) virrey D. Perafan de Ribera, marqués de Tarifa, féu gran festa de córrer de toros en la plaza del Born, y aprés jugà cañas ab molts cavallers de ciutat» (Vargas, 1961: 429); i continua al segle XVII: «Diumenje a 21 de abril 1630. En casa del Duch de Cardona, al Pla de St. Francesch, en Barcelona (...), hagué-y també córrer de toros. Lo primer joch fou bona vista; los toros, cosa molt bruta, perquè los cavallers los dejarretàvan y los flamenchs o húngaros de la guarda al punt los trossejàvan» (Casas Homs, 19751976: 229). Igualment, els diccionaris de Font (1637), Torra (1653) i Lacavalleria (1696) recullen l'expressió córrer toros, llatí agitare tauros, i el diccionari de Torra també jochs de bous o córrer de toros «boalia, ium, vel orum, bupetiae, arum, bupetii, orum», amb la preposició $d e$.

En l'edició de Barcelona de 1580 del Thesaurus puerilis de Pou, apareix la mateixa construcció, però amb bous: «Córrer de bous. Boalia, lium; bupetiae, arum, bupetii, orum» (f. 25). ${ }^{34}$ Així mateix, Coromines (DECat, II, 956) dóna compte de «la construcció mig-substantivada» córrer-de-bous, que troba en un text val. de l'any 1460: «molts balls, dances juntes, córrer-de-bous e altres festes». També es troba substantivat per l'article, però en aquest cas sense la prep. de davant bous, en: «Del cadafal que tans moriren del córer los bous» (a. 1472) (Rodrigo 2011: 413). Cal citar, així mateix, en relació amb aquestes formes, la festa de corre bous, que documentem a principis del s. XV, en l'acord del Consell General de la Ciutat de València per celebrar l'elecció del nou rei Ferran d'Antequera: «En aprés lo present Concell, per mostrar maior alegria de la molt desijada declaració e publicació de nostre rey e senyor, e ajustant festa a festes, concordantment provehí e ordenà que digmenge primervinent $[10$ de juliol de 1412] siga feta en lo Mercat de la dita ciutat gran festa de corre bous, e sien correguts thoros e bous, per mils festivar lo novell gotg de la dita declaratió»

33 En cast. antic també era ben conegut correr de toros, que doc. des del $\mathrm{s}$. XV, anàleg al cat. córrer de toros (i de bous); exs. «Tubo en alguna manera travajoso parto e parió vna hija, por cuyo nasçimiento se hizieron alegrías en la corte de muchas justas, juegos de cañas y correr de toros» (Diego Enríquez del Castillo: Crónica de Enrique IV, c. 1481-1502, ap. CORDE), «de «las danças, justas, torneos, correr de toros, jugar de cañas y de otros muchos passatiempos sin cuento» (en fr. «combat de toreaux») (Juan de Flores: Historia de Aurelio y Isabela, mejor corregida que antes, puesta en español y francés, Anvers, Jean Richart, 1560), ací juntament amb «jugar de cañas», que es troba en altres textos cast. antics, mentre que en cat. és habitual «jugar a canyes»; «Nuestro Pedro Mexía dice que el primero que corrió toros fue Julio Cesar, pero muy más antiguo haze este regocijo Alexandro de Alexandro, porque en Grecia uvo el correr de toros, y en los theatros y amphitheatros y circos máximos avía corrales para los toros» (Gerónimo Román: Segunda parte de las repúblicas del mundo, Medina del Campo, Francisco del Canto, 1575, p. 339).

34 No figurava en la primera edició de 1575 (València, P. de Huete). En la traducció de la part catalana del Thesaurus (València, 1615), a càrrec del valencià Bernabé Soler, es tradueix per «correr toros. Agitare tauros» (p. 36). 
(AMV, Manual de Consells, A-25, f. 74r), ${ }^{35}$ que cal relacionar amb la festa de córrer bous, que hem vist més amunt en un text val. de 1417. Igualment, en el Dietari de Porcar llegim correbous: «Dit dia de dimecres, a 2 de maig [1618], en la plaça de la Olivera tingueren llicència del señor virey de correbous sol[t] s. Y feren grans tanques y cadafals, y los bous tancats en un corral de dita plaça» (CICA: f. 296v, 1. 20). ${ }^{36}$

Si el vincle de corre (i corra) de toros amb el verb córrer és evident, no oblidem tampoc l'afinitat, tant formal com semàntica, que mantenen corre (corra) de toros i córrer de (dels) toros amb corro de toros (i de bous), referits tots a la festa taurina, en la qual es corren toros, que podria haver suposat històricament algun tipus de relació secundària entre aquests conceptes i mots. ${ }^{37}$

El substantiu corro figura en els diccionaris valencians del s. XIX, per referència al lloc on es tanquen els bous que han de torejar-se, i com a sinònim de rogle. En Escrig (1851) corr o corro 'corro o rolde', 'toril', en EscLl i MGad: corro «corro. Lo mismo que rogle. // Toril: sitio o paraje en que se enjaulan los toros para correrlos en alguna parte», que el consideren d'origen cast. Com a sinònim de rogle no figura en el $D C V B$ ni el $D E C a t$, però el trobem en textos valencians d'intenció popular dels segles XIX i XX, i continua en l'actualitat; ex. «La moma (...). De gent se fa un corro, / y sues a jorro, / pués tots s'apinyoten, per vore'ls ballar, / però no t'apures, / que eixes apretures / quansevol les pasa, si és bon valencià» (Festes Valencianes, 2, 1915, p. 5), «Habia un joch del corro, més propi de xiques, que degué ser importat de Cataluña o Mallorca, pués que la lletra corejà dia: «La bolanchera del topí / sense foch la fa bollí. / Pega-li foch y bollirà! / La bolanchera rodarà»» (Revista de Castellón 61, 1914, p. 10); en sentit figurat armar-se corro 'moure's gresca': «Tano: -Ben charrat està, compare. / Dempués tornarem, vitat? / Cualo: -A vore qui t'ha furtat / a la filla de sa mare. / Tano: -Pos no·s va·armar flux catarro! / No sé si s'armarà

35 És probable que es tracte, com en els exemples barcelonins de corre (corra) de toros, de l'infinitiu de CURRERE, que veiem en l'expressió sinònima i contemporània la festa de córrer bous (València, 1417). Encara que en els textos valencians medievals, a diferència dels plurals, no és habitual la caiguda de la $-r$ final en els singulars, aquesta no hi és absent; sobretot en certs mots, com, precisament, l'infinitiu corre, que es troba diverses vegades en el Llibres de Cort de Justícia de Cocentaina (1269-1295) (veg. Ponsoda 1996: 181-182; CICA), i de València (1279-1321) (veg. Diéguez, 2001: 70-71; id., 2002: 16; CICA). De fet, Ponsoda afirma que la forma corre de Cocentaina «pot interpretar-se com un infinitiu normal, així com ocorre en querre / querer / querir, en vençre / véncer, etc.», i no ser un cas de pèrdua posterior de la -r final. Igualment, Duarte (1991: 19), en la seua anàlisi de la llengua de les Costums de Tortosa, troba que en aquest llibre la - $r$ es manté generalment en posició final absoluta i s'elideix en el grup final - $r s$, amb algunes excepcions aïllades de caiguda -si més no gràfica-, com l'infinitiu acorre, la qual creu que pot explicar-se, «potser com a variant procedent de CURR(E)-RE o fruit de la concurrència abans i després de la vocal $e$ de dues vibrants».

36 Segons el $D C V B$, correbou és compost de corre (imperatiu de córrer) i bou. Siga com siga, pensem que no es pot desvincular, ni històricament, ni semànticament ni formalment, dels tipus córrer de (dels) toros (de bous), corre (corra) de toros, córrer bous, córrer (córer) los bous.

37 Sobre la relació en castellà entre corro de toros, corrida de toros i el verb correr, Malkiel (1989: 18) considerava que «el giro corro de toros, incontrovertible predecesor de la corrida de toros de nuestros tiempos, revela una alusión al verbo correr». 
corro!...» (En la velà..., p. 12), i traure (quelcom) a corro 'esmentar-ho, parlar-ne': «-D’alguna sita (...) / ve vosté. / -Yo? Tens raó: / la marquesa del pendó, / parenta de la Catalanga. / (Mereix que li fique el puñ...). / Qué ve el traure sita a corro?» (Palanca: Secanistes de Bixquert, Xàtiva, 1867, p. 12). ${ }^{38}$

Coromines $(D C E C H, \mathrm{II}, 203)$ recull corro en castellà en un doc. del s. X, on sembla significar 'corral', i després no torna a trobar-ne exemples fins al s. XV; igualment, Alonso (1986) registra corro 'cerco que forma la gente para hablar, para solazarse, etc.' i 'espacio circular o casi circular' al s. XV. ${ }^{39}$ Aplicat a l' 'espacio circular o arena de la plaza de toros', tant el DCECH com Alonso (1986) no el recullen fins el Vocabulario español latino (c. 1495) de Nebrija: «corro del toro: harena, theatrum», i ja no tornen a donar-ne referències..$^{40} \mathrm{El} D C E C H$ recull en port. ant. côrro 'circo, área onde se correm touros, ou se faz feira, ou se da algum espectáculo'. ${ }^{41}$ Alguns diccionaris castellans o bilingües dels segles XVI i XVII sí que esmenten aquest sentit de corro de (del) toro, per ex. Percivale (1591) corro de toro «hunting the bull; agitatio tauri», Oudin (1607) corro de toro «lieu où l'on fait courir les taureaux», Franciosini (1620) corro o cosso de toro «la piazza doue corrono i tori» (NTLE), però el sentit taurí no figura en la documentació reunida en el Corpus del Nuevo Diccionario Histórico del Español, en el Corpus del español, ni tampoc en el CORDE, a excepció d'El Cortesano (1561) del valencià Lluís del Milà, on apareix dues vegades en català (corro de bous) i una en la part castellana (corro de toros). Aquest sentit de corro no figura tampoc en el Diccionario de Autoridades (1729), ni en les edicions posteriors del DRAE, que només inclouen coso (cosso) (NTLLE). En canvi, sí que recollia corro Siesso de Bolea (1715-1724), com a veu aragonesa, equivalent al cast. coso: «corro. «Entraron por el corro». En Castilla, cosso» (Aliaga, 2008: 130).

Documentem corro de toros 'correguda de bous' en un text procedent de la Comunitat d'Albarrasí, de 1591-92 (Martí 2011), i al s. XVII en documents en castellà relacionats amb Aragó i amb València, ex. «Que corro de toros es ver en un oficio d.estos un juez desatinado» (Del senado y de su príncipe. Por fray Juan de Madariaga, monge de la cartuxa de Portacaeli, València, Felipe Mey,

38 Cf. en cast. echar en corro, echar en el corro 'decir algo en la conversación sobre que todos platiquen' (Cejador 2008: 177).

39 Encara que poc nombrosos, se'n poden trobar, però, exemples medievals anteriors al s. $\mathrm{XV}$, per ex., en Alfonso X: «Et la contienda deste vençer o ser vençidos fazien la corriendo en corros con bestias segunt el vsso de aquel tienpo» (a. 1284, General estoria, ap. CORDE), o en documents notarials: «todos aqueillos bienes o rentas pertenescientes al seynnor rey fuessen pregonados et puestos en corro pora cada uno de sus oficiales» (a. 1358, Cuentas de la bailía de Tudela, ap. CORDE).

40 S'aproxima a aquest sentit la cita de la General estoria que s'inclou en la nota precedent, on està present el combat entre un home i una bèstia, en un corro, per relació als antics romans.

41 Malkiel (1989) tracta de justificar que corro no va ser una veu comuna en la literatura medieval castellana, almenys abans del s. XV, tenint en compte el seu caràcter de «voz rústica, que muy lentamente se puso de moda en los ambientes literarios de la Península» (p. 26), i relaciona «la infiltración tan tardía de corro en el léxico del español literario con la presión cultural del Oeste de la Península sobre el Centro, la cual se manifestó allá por 1400» (p. 27). 
1617, p. 234), «en un corro de toros que huvo en la plaça de Predicadores por Carnestoliendas, un subdiácono mató un hombre, y se entró en casa Don Juan Valterra» (Libro de la santa vida y milagros del illustríssimo y reverendíssimo señor Don Fr. Thomás de Villanueva, arçobispo de Valencia (...). Compuesto por el P. M. F. Miguel Salón, de la misma orden, calificador del Santo Officio y cathredático de Theología en la Universidad de Valencia, València, Juan Chrysóstomo Garriz, 1620, p. 193), «Vase llegando ya la hora y punto / para el corro de toros aplazado. / De arena muy menuda está la plaça / sembrada toda» (Los amantes de Teruel. Epopeya trágica. Con la restauración de España por la parte de Sobrarbe y conquista del Reyno de Valencia. Por Juan Yagüe de Salas, secretario de la ciudad de Teruel. Dirigida al Concejo y Ayuntamiento de dicha ciudad, València, Pedro Patricio Mey, 1616, p. 414), «Házese una justa en la Corte; aý acude el rey, los príncipes, los nobles, los ciudadanos y plebeyos; a un corro de toros todos acuden, y se ponen a vista para mirar cómo sale el toro, y cómo emprende al toreador, cómo él se defiende, se desvía, lo jarreta o le clava el garrochón, con que le rinde a sus pies» (Tomo primero de cinco que contienen las homilías sobre los Evangelios de la Quaresma. Escritas por el reverendíssimo Don Fray Gerónymo Batista de Lanuza, de venerable memoria, siendo obispo de Barbastro, añadidas por él mismo, siéndolo de Albarrazín, Saragossa, por Juan de la Naia y Quartanet, 1636, p. 178), on es llegeix una breu descripció de l'acció del «toreador» amb el toro; «Si es buen remedio por la tristeza y melancolía saliros a una huerta de árboles diversos, o entraros en un jardín matizado de flores, o saliros a un monte a espaciar la vista, con que se desahoga el coraçón; si lo es un sarao, o juego de cañas o corro de toros, donde se veen tantas galas, tan buenos y diferentes rostros» (id., tomo quarto, p. 211). Entre els autors castellans de l'època, trobem corro de toros en Lope de Vega, el qual, com és sabut, va estar un temps residint a València: «Estos eran sus decoros, / que los fronterizos moros / hazían exercitallas / mejor allí con batallas / que agora en corros de toros» (Isidro. Poema Castellano, Madrid, Luis Sánchez, 1599, p. 59), «Huvo un corro de toros, otro dia / salió Don Juan» (La piedad executada, en Decimoctava parte de las comedias de Lope de Vega Carpio, Madrid, por Juan González, 1623, p. 161).

Actualment, corro 'reses bravas que llevan por los pueblos para torearles en las fiestas' és conegut en la comarca Gúdar-Javalambre (López Navarrete, Torres Belmonte, 2008: 50), i a altres comarques aragoneses meridionals, ${ }^{42}$ però no

42 A Cantavieja (El Maestrat): «las tres ultimas fiestas (...) han exhibido un total de 7 corros de vacas de las ganaderías de Germán Vidal, por partida doble, Juan José Laparte, Hnos. Ozcoz, Dilla y Villagrasa, Hnos. Marcén y Vicente Domínguez», «El corro de vacas estaba compuesto por vacas de seria arboladura que mostraron su bravura a los pocos que les plantaron cara, se la jugo «MANOLO» con un corro de vacas duro y que no es la mejor escuela para el que empieza», «Germán Vidal trajo un corro de vacas muy serio, compuesto en su mayoría por animales que ya habían pisado ya la arena de esta plaza» (http://www.festejospopulares.net/cronicas/2006/45_cantavieja_2006/cantavieja.htm); a Mosqueruela (Gúdar-Javalambre): «El 16 de junio fiesta en Mosqueruela, a las 5 corro de vacas de la ganadería Hermanos Navarre» (http://www.foro-ciudad. com/teruel/rubielos-de-mora/mensaje-366285.html), a Gea de Albarracín: «Charanga y encierro tradicional por las calles de la localidad, en el momento que lleguen los toros. Cuando éstos estén en los toriles corro de vacas» (http://www.geadealbarracin.com/fiestas_2003.htm). 
sembla ser-ho a l'Alt Aragó (no figura en l'Endize ni en altres reculls de vocabulari altaragonés). Aquest sentit es coneix també en els parlars castellans de base aragonesa del País València, com a l'Alt Palància (cf. Martí, 2010), així com en valencià. ${ }^{43}$

Per concloure, el mot corro, en les seues aplicacions taurines, amb els diferents matisos que hem anat repassant, té una presència històrica prou rica $\mathrm{i}$ variada en valencià, on es registra des del s. $\mathrm{XV},{ }^{44} \mathrm{i}$ compta amb documentació i testimonis orals fins l'actualitat. En canvi, en castellà en coneixem un desenvolupament documental molt escàs, llevat de les fonts aragoneses i valencianes, i només manté una major presència en la lexicografia dels segles XVI i XVII. No resulta estranya, doncs, la participació aragonesa en la transmissió de corro de toros al valencià dels segles XV i XVI, ${ }^{45}$ on el mot corro arribaria, en efecte, relacionat amb els bous, més encara si tenim en compte la importància d'Aragó en la transmissió al valencià de mots de l'àmbit ramader. Molt més tard, ja en dates recents, corro ha desenvolupat també en val. el sentit de 'rogle', en aquest cas influït directament pel castellà.

4. brosquil: «En suma, ells se compongueren, / y estaven tan imitats / com aquells [bous] qu.en los brosquils / pasturen per ses marjals» (Romanç entretengut, 172).

En el DCVB brosquil 'bosc espès, quasi intransitable' (les Paüls, Tortosa, Maestrat), i brusquil 'bosc espès, de pas difícil' (Tortosa), ${ }^{46}$ sense doc., der. de brusca 'llenya prima', «amb la $o$ presa per influència de $b o s c »$. Segons Coromines (DECat, II, 305; DCECH, I, 675), brosquil i brusquil 'bosc espès i embardissat' (Tort., Maestr.), sense doc. cat., si bé afirma que «se extiende mucho más al Sur en tierra valenciana, como apelativo, y también como nombre de lugar», i cita en aquest sentit les partides el Brosquil de Cullera i de Sueca. Mot, com diu el mateix autor, compartit amb l'aragonés brosquil 'redil', procedent de brusca 'llenya menuda', ${ }^{47}$ amb el canvi de brusquil en brosquil per ultracorrecció del

43 A Vilafranca del Maestrat: «De vesprada es va soltar un corro de bous de Germán Vidal, que va ser un poc avorrit, per falta de toreros i poques ganes d'alguns animals» (http://usuarios. lycos.es/bousvilafranca/), a la Serra d'En Galceran: «A la mitja part, es farà entrega dels premis: al millor bou, a la millor vaca i al millor corro» (http://www.sierraengarceran.es/ca/event/2008/05/02/ list/all/all), a Llíria: «A continuació, se soltarà un corro de vaques de Vicente Machancoses i una vaca embolada a càrrec de la Penya Raval» (http://bousdepoble.blogspot.com.es/2010/09/cartellde-bous-lliria-2010.html).

44 No és absent tampoc en la documentació del Principat.

45 Casanova (2002: 1672) ja intuïa l'origen aragonés de corro en valencià.

46 Per a l'ús tort. de brusquil, veg. també Beltran (2010), aplicat a un «bosc espès, de difícil ingrés o pas», un «lloc de brossa sorrat de malesa alta».

47 Ara bé, Coromines afirma que «hi ha algun contacte secundari amb l'arag. borguil» $(D E-$ Cat); segons el mateix autor, en arag. borguil o maestr. borguil (bu-?), «que tiene un sentido igual o muy parecido al de arag. brosquil 'redil' (...) y el ronc. y nav. burrusquila» (DCECH, I, 626), que a Ansó correspon a borregaril, borragaril, der. de borrego + -aril (<-ARE + -ILE), i considera molt possible «una contracción casi haplológica en *borgril > borguil o *bosgril > brosquil». 
canvi metafònic $o>u$ davant de $i{ }^{48}$ Aquest filòleg creu que brusquil designaria primerament el 'cercado de maleza y broza en que se encierra el ganado', d'acord amb les condicions primitives del pasturatge a Aragó. En el DCECH brosquil es doc. per primera vegada en el Diccionario de Autoridades (1726), com a veu aragonesa: «lo mismo que redil de ovejas. Es voz que sólo tiene uso en el reino de Aragón» (segons el diccionari acadèmic, cf. NTLLE); un poc abans el va recollir Siesso de Bolea (1715-1724): brosquil 'redil donde se tienen los recentales', per referència als «cabritos y corderos» (Aliaga 2008: 103). ${ }^{49}$

Martines (2012b: 155) aporta documentació medieval de brosquil en cat., en els Establiments de Castellfort $i$ aldees de Morella (c. 1370-74) (brisquils, que es pregunta si probablement caldria llegir brusquil) i en els Establiments de Llucena (s. XV) (brosquil), «que lliguen brosquil amb aqueix sentit ramader ('part o tipus de corral on s'aparten alguns animals')», que té el mot en arag. Al s. XVI el documentàvem en el Libre de Antiquitats de la Seu de València, també relacionat amb el bestiar boví: entre els obsequis que el capítol de la Seu va fer al legat pontifici Joannes de Salviatis en la seua visita a València, «ans de cavalcar per València, lo reverent capítol li trameté hun present, ço és, dos vedelles vives excel-lents de brosquil, XX parells de polles belles, XX parells de pollastres, XX parells de ànedes y XX parells de colomins, tot penjat en barres de fusta» (Martí 1994: I, 107; II, 292) i bresquil en uns processos d'Albalat de la Ribera (cf. CICA).

Apareix en el Dietari de Porcar: «Y aprés vingué orde de dit virey que no·s correguesen [los bous], sots grans penes, y les executaren; perquè tan prest no.ls desfeyen. Y hagueren de traure los bous més que de presa del corral y portar-se-n al Brosquil» (a. 1618) (CICA: f. 296v, 1. 20), que l'editor interpreta com «un lloc concret» (Lozano 2012: 481).

En l'exemple citat més amunt del Romanç entretengut de Carles Ros designa un indret de pasturatge natural, destinat, en concret, als bous. Remeten també a un lloc que «s'a criat» per a les bèsties els versos següents d'un col-loqui

48 Segons el $D C E C H$, «hoy se emplea en Echo, en la provincia de Teruel y en localidades de Soria».

49 En arag. brosquil, brusquil 'parte de un redil, destinado a separar del resto a las reses pequeñas; se prepara en un rincón del redil', 'sitio para encerrar a los corderos', 'redil', 'bergazo pequeño', 'rincón para poner un animal', 'división de una cuadra formada tras levantar un tabique', 'corralico donde engordan los ternascos' (Endize), 'pajera en donde ponen las ovejas que rechazan lactar sus crías' (Moneva 2004), 'cuchitril (o sustituto) que hay en la majada para meter a los cabritos recién nacidos' (ALEANR, m. 620), amb la var. brosquín 'habitación pequeña, obscura, donde los pastores meten a los corderillos para que no les dé la luz y su carne sea más blanca' (Andolz 2004), entre altres variants, que es poden consultar en l'ALEANR. A Terol brosquil 'lugar de broza, cubierto de maleza alta' (Vázquez 1994: 260), amb un sentit més pròxim al tortosí. El mot arriba a Navarra: brusquil 'lugar sin luz donde se encierra a los cabritos, chivos y recentales, apartándolos de sus madres' (Iribarren 1952), a la Rioja: brosquil 'habitáculo que hay en la majada para meter a los cabritos recién nacidos', 'en los apriscos, cubierto donde se atan las ovejas a fin de que amamanten los corderos que no son suyos' (Pastor 2004), a Guadalajara, nord-oest de Conca ('cuchitril en la majada para cabritos recién nacidos'), la Manxa i nord-oest de Múrcia, amb sentits i variants formals diferents (cf. Martines 2012a: 154-155). 
valencià del s. XVIII: «Fillet, pacència, / ya que el número as de créixer, / que el ser casat y cabró / ego sum y tu lo eres. / Y, així, alçaràs los dos muscles / y aguanta aqueixes tarees, / que el brosquil no s'à criat / per a que lo ocupen bèsties, / sinó per a mi, per a tu, / y tal volta per a eixe» (BV, ms. 419, Coloqui de la churra, p. 114; veg. també Martí 2006).

Actualment, brosquil sembla ser, com a apel-latiu, un mot poc habitual en val. general, però no totalment desconegut. No figura en els diccionaris valencians actuals generals o d'ús, a excepció de López Verdejo (2010): brosquil 'lloc molt poblat d'arbres, abruixells o brossa', i el $D N V$ 'bosc espés'; també l'arreplega Reig (2008: 67-68): brosquil 'bosc molt compacte i embardissat, és a dir, que està molt poblat d'arbres i matolls, i és pràcticament intransitable', i en sentit figurat $\mathrm{i}$ amb caràcter vulgar 'pèl púbic, especialment el d'una dona' ${ }^{50}$

Els diccionaris valencians del s. XIX (Escrig, EscLl, MGad) només el recullen, en la variant formal brosquill, en sentit figurat, en la locució vés al brosquill «anda, vete enhoramala» (Escrig), «que se emplea para denotar disgusto, enfado o desaprobación» (EscLl, cf. MGad).$^{51}$ L'expressió al brosquil es troba també en textos valencians d'inspiració popular dels segles XVIII i XIX. Així, en la Rondalla de rondalles (p. 51, 67-68) de Lluís Galiana es fa servir per rebutjar o desfer-se d'una persona inoportuna o menyspreable.$^{52}$ Igualment, es llegeix en l'obra dramàtica de Francesc Palanca i Roca, com a expressió de contrarietat, de desesperació: «Cosme: -Desidixca's, / y tot s'arregla en un tris. / Yo y vosté marit y molla. [a Antònia] / (...) -Andreu: -(Bon guisao!). / Cosme: -Andreu, sotana. / Andreu: -(Ya no m'aguante. Al brosquil!). / Cosme: -Vecha'l yo en bonet y estola... / Andreu: -O en un trabuc, pegant tirs! / Antònia: -Andreuet! / Cosme: -Qu.ès lo que parles? / Andreu: -Que no hi à res de lo dit / (...) / Que no cante misa. / Que m'agraen d'atre estil» (Lord Guillaume, BMCV, ms. MG 158, [estrenat en 1884], f. 15v) ${ }^{53}$ Es troba també en l'escriptor de Beneixama Joan B. Pastor Aicart (1849-1917), en la seua obra Plucha d'estiu: «-La vullc que tinga chuí. / -Pués busca una chica pobra, / però que siga un espill / de honradez... / (...) -Pués ne conec una aixina... / -Pués si me vols creure a mi, / declara't, casa't en ella, / y a treballar, y al brosquil» (Martínez 2010: 289), amb

50 En el seu llibre es proposa, segons les paraules de l'autor (p. 12), recollir una sèrie d'unitats lèxiques, «genuïnament valencianes i especialment interessants, bé per la seua raresa, bé perquè es troben en perill de desaparéixer pel fet de ser poc conegudes o bé perquè hi ha tendència a usar-les indegudament o substituir-les per altres menys genuïnes».

51 Amb palatalització de la lateral, per efecte de la vocal palatal en contacte, i potser també per la -s final del plural, cf. pernil - pernill, pletil - pletill, naril - narill, toril - torill (veg. DECat, V, 882; VI, 614; VIII, 616), sense descartar-hi tampoc una possible influència analògica.

52 Possiblement hi està present en el seu origen el sentit de lloc silvestre, poc transitat per les persones, que solia ser destinat al bestiar; volent indicar que hom l'enviava a un lloc allunyat, on no moleste, i a més hi subjau una idea degradant d'animalització.

53 Cosme pretén que el seu nebot Andreu es faça capellà, però aquest, igual que el seu oncle, està enamorat d'Antònia; per això, Andreu, quan s'assabenta de les intencions de Cosme, pres de la desesperació, reacciona eixint del lloc on es mantenia ocult, i es decideix a declarar obertament els seus propòsits al seu oncle, encara que així pose en perill la seua herència. 
la qual hom deu voler expressar rebuig cap a les coses vanes i insubstancials, $\mathrm{i}$ acceptació de la vida senzilla basada en un matrimoni feliç i un treball honrat.

Com a topònim, el Brosquil es localitza a la Plana Baixa (Nules), l'Horta (València, Puçol, el Puig) i la Ribera Baixa (Cullera, Sueca, Sollana, Corbera) (TPV; OnCat, III, 123), i sovint designa indrets pròxims a la mar, o de marjal. A Cullera: el Mareny del Brosquil és una partida de mareny, fronterera al mar; doc. «partida del Mareny del Brosquil» (a. 1845), i més antigament, en plural: «in partita dicta dels Brosquils» (a. 1599), i el derivat Brosquilars: «en la partida de les Chafarines, als Brosquilars...» (a. 1613) (Giner 1986: 138). En l'amollonament dels límits de l'Albufera, el 21 de març de 1577, es documenta lo Brosquil, en el terme de Sueca: «fonch posada la cinquanta-cetena fita en la dita partida de Sueca, davant lo Brosquil, junt a la cèquia del Rey» (Freire 1995: 255). A Puçol el Brosquil és el nom d'un camí, d'una sèquia i d'una partida, «sense que es conega el significat», doc. 1727: «Brosquil» i 1796: «Brosquils» (Alcaide, Ferrer 1986: 21). La partida del Brosquil de Nules «sembla que va tenir problemes de drenatge fins temps recents, cosa que ocasionava el creiximent d'una vegetació exhuberant» (Vicent 1985), doc. «una margal camí del Cabeçol, al Brosquil» (a. 1682); al mateix terme es doc. el brosquil de Palomar: «Per una marjal al brosquil de Palomar» (a. 1607), el brosquil de Vila-roya: «Terra marjal al brosquil de Vila-roya» (a. 1607) i el brosquil d'Agost: «terra marjal camí del brosquil de Agost» (a. 1622), on comprovem la presència al terme de Nules de diferents paratges designats com a brosquil, tots ells de marjal.

En relació, així mateix, amb el pasturatge del bestiar boví, Teodor Llorente Falcó es refereix en les seues memòries a la partida de Cullera «llamada del Brósquil», ${ }^{54}$ on anaven a pasturar els bous i vaques: «Entre las poquísimas ganaderías que aquí se criaban, y no de reses bravas, había una que se hizo muy popular. Era su dueño don Manuel Sapiña (...). Dicha ganadería apacentaba unas veces en una partida de Cullera, llamada del Brósquil (sic) (...), y la formaban una serie de vaquillas y de marrajos que sabían más que Lepe, Lepijo y su hijo» (2001: I, 409). Cf. també com a topònim pròxim a la ciutat de València: «li digüen al seu marit: / "Me'n vach a les cuarant-hores, / que ara estan en Sen Martí". / Y pasen a Sen Llorens; / y a voltes hasta el Brosquil / peguen una escorreguda, / y es guañen per a un vestit. / Y a poqueta nid, a casa, / y no fan falta al seu llit» (Martí 1997: 291), «Com l'anomenada estava / que havia de predicar / el capellà de Tarugo, / vingué chent de vora mar, / de Pinedo, del Brosquil, / y els peixcadors del Palmar, / y tota Rusafa en pes» (Martí 1994: II, 292).

Sense excloure la possibilitat que en el Romanç entretengut i en el Coloqui de la xurra el terme brosquil pogués ésser un topònim, creiem que pot entendre's, així mateix, com a apel-latiu, sense oblidar que els topònims valencians que hem vist deuen tenir l'origen en les característiques dels llocs als quals

54 Deu tractar-se d'un error, ja que tant en el TPV i l'OnCat, com en Giner (1986), es recull sempre Brosquil a Cullera, amb accentuació aguda. 
s'apliquen. Per tant, és ben probable que el substantiu brosquil, si bé actualment s'ha envellit en val. general, hi fos més conegut en altre temps.

Per últim, ens agradaria recordar que el mot brosquil dóna lloc a derivats en terra valenciana: el verb embrosquilar-se 'ennuvolar-se', 'embriagar-se', 'embullar-se, posar-se en situació difícil un assumpte', registrat al Maestrat $(D C V B),{ }^{55}$ derivat, segons el DECat (II, 305), de brosquil. És conegut, així mateix, més al sud, a la Plana Baixa: «En giner (...), / temps de mar embrosquilat / i cel de ull de peix i blau, / com també el més apropiat / pa fer rata de cacau» (Peris Fuentes: Poesies, València, 1928, p. 104), i el fa servir l'escriptor de la Costera Toni Cucarella, aplicat també a l'oratge nuvolat: «Dia de setembre. Vesprada de dissabte. A pesar de l'oratge embrosquilat de darreries d'estiu, mamprenen les bicicletes» (On habiten els déus de la Costera, en Notícias 7 días, 10 de maig de 1997), «L'oratge pintava embrosquilat, si ploc no ploc» (http://blocs.mesvilaweb.cat). Uns altres der. són: els Brosquilars de Cullera, citat més amunt, i el brosquileral del Maestrat (cf. Gimeno, 1998: 347), formats amb els sufixos col-lectius de vegetals -ar i -al.

5. garranxó: «los torejadors clavaren / als torets, fent com qui juga, / los garranchons y rosetes, / en visch, serol y pegunta» (Romanç nou de la correguda, 224). Amb un sentit semblant, tenim: «Fas conte que a la manera / que el bou sent el garranchó, / gruñirà com un bacó / el sacristà Ramón Cabrera» (a. 1839) (Décimas que se han de arrojar desde los carros triunfales en las fiestas que celebra la ciudad de Gandia con motivo de la paz, València, impr. de Gimeno), i jugant al bou els xics: «Jugar al bou. (...) Les corregudes de bous, en la mà nua o pedra, en bastó, en bou de fusta en cuernos autèntics de bou o de borrego s'han fet, se fan y se faran. (...) Destrosa dels pantalons (...), ferides dels garranchons, dels cuernos o bañes, de l'armasó de fusta (...), y tants objectes que s'utilisen en tota correguda» (Revista de Castellón 62, 1914, p. 5). També el documentem en val. al s. XIX amb el sentit d' 'esgarrinxada, petita ferida produïda en la pell', ex. «-Ay, el dit! / -Això qu·és? / Ay! / Què s'ha fet? / -Un garranchó. / -Com? / -El malaït papagall, / qu.estant yo chuant en ell, / m'ha arreat tal picotà / que me s'ha emportat mig dit» (Ovara: Un aprenent de lletí, València, 1879, p. 8), en un altre lloc del mateix sainet es diu que és un arrap o un tall (p. 9); «Pillo, gandul, trapaló! / Ya.t conec, no cal que maldes, / alguna sistella en faldes / t'ha fet eixe garranchó!» (Ovara: La guerra en Pau, València, 1885, p. 287), per un «arrap en la cara» (p. 286) que té el marit.

En el DCVB garranxó 'ferida o esgarrinxada causada amb un branquilló', procedent d'EscLl; juntament amb garranxa 'bastó que té alguns branquillons a manera de ganxos, i que, penjat al sostre o a una barra horitzontal, serveix per a tenir-hi penjat el llum, les cistelles, les botifarres, etc.' (Ribagorça, Conca de Tremp, Urgell, Tortosa) ${ }^{56}$ i 'esgarrinxada' (Grandó Voc.

55 En el Tresor (V, 293) de Griera amb -ll-: embrosquillar-se 'ennuvolar-se', 'emboirar-se', embrosquillat 'tapat, cobert de núvols' (Benassal).

56 També a la Llitera: garranxa 'garanxa, perxa rústega que es penja del sostre' (Giralt 2005). 
ross.), que considera «forma femenina del cast. garrancho»; garranxada 'esgarrinxada' (Labèrnia-S. Dicc.), garranxo 'branqueta trencada o arrancada d'un arbre o planta' (Maestrat, Cast.), «probablement pres del castellà», ${ }^{57}$ i la var. garranx, procedent d'EscLl. Abans en Escrig (1851) garranig, garranjo, garranget i garranjà, ada 'herida o desgarro causado con un garrancho'. MGad inclou també el pl. garranxos, com a sinònim de pallots: «els garranjos que.s deixen els animals en lo pesebre. Baballas: desperdicios de paja y hierba seca». Amb els exemples de més amunt del teatre popular valencià, veiem que garranxó s'hi aplica en general a una ferida en la pell (en aquells casos produïda pel bec d'un papagall o per les ungles d'una persona), i no únicament a una ferida causada per una branca o branquilló, com solen recollir els diccionaris.

Coromines (DECat, IV, 383), que no enregistra garranxó, nega que el cat. garranxa 'perxa rústega feta d'una branca penjada al sostre', 'rama d'esbarzer', garranxo 'estaloc' siguen manlleus del cast., i creu que surten de l'encreuament de garra amb ganxo, ganxa, ${ }^{58}$ així com el cast. garrancho 'parte saliente de una rama o tronco', 'ramo quebrado' prové «de un cruce de garra 'rama' con su sinónimo gancho» (DCECH, III, 106). Afirma que en cat. garranxo és propi «del Migjorn», a través de la informació d'Enric Valor (sinònim d'estaloc), i del Maestrat (segons Carles Salvador). Diu, així mateix, que en espanyol garrancha és de l'Alt Aragó (cf. DCECH, III, 106), ${ }^{59}$ i garrancho en cast. apareix «en textos suspectes de lleonesisme o andalusisme (...), car avui és localisme andalús garrancher (...) i garrancho del Bierzo (...), des d'on s'interna pel Nord de Portugal». El der. garranchón no figura en el DRAE, el NTLE ni el DCECH, però el trobem en fonts cast. actuals, que enllacen amb el sentit de ferida $\mathrm{o}$ esgarrinxada que té garranxó en val., ${ }^{60}$ el qual cal, doncs, relacionar amb la veu cast., com s'ha de vincular el cat. garranxo amb el cast. garrancho. ${ }^{61}$

57 Al Baix Vinalopó garranxo 'xiquet entremaliat' (Segura 2003: 217), que cal relacionar amb el murcià garrancho 'persona arisca y de trato difícil' (Ruiz, 2007: 305); significats metafòrics.

58 En el DCECH (III, 68) Coromines afirma que el cast. gancho es va estendre, entre altres llengües al cat.; en canvi, en el DECat (IV, 343, 383) diu que és d'origen mossàrab en cat. Per la seua part, el $D C V B$ considera ganxo un castellanisme.

59 Cf. la continuïtat de garranxa en cat. nord-occ.

60 Cf. garranchón 'desgarrón en la ropa o en la carne hecho por algo punzante' (Sierra de Cazorla) (Alvar 2000: 399), 'rasguño profundo producido por un gancho de una planta o un hierro' (la Alpujarra de Granada) (http://alcazardevenus.es/vocabulario), 'lesión producida en la piel con un objeto metálico o árbol' (Almeria) (http://lamedicinapopularenelmediterraneo.blogspot.com. es), 'enganchón, rasgón, rotura en una tela o en la carne' (Astúries) (http://canales.elcomercio.es/ extras/diccionariu), 'enganchón, que puede ser o bien en la ropa o bien en la piel, normalmente con el sarmiento de una cepa' (Fuentealbilla) (https://groups.google.com/forum/\#!msg/los-viejos/ Fb_figKvUtI/R67TMxq919UJ), 'desgarradura en un vestido producida por un garrancho' (Soria) (Manrique, 1956: 28).

${ }_{61}$ En cast. garrancho es doc. des del s. XV, i no únicament en textos lleonesos o andalusos (cf. CORDE, NDHE, cf. NTLE), i actualment té una major extensió que la referida en el DCECH, com ho podem comprovar consultant els vocabularis dialectals accessibles en Internet (províncies de Cuenca, Ciudad Real, Segovia), o altres (Múrcia, Ruiz, 2007: 305; Gúdar-Javalambre, López, 
Per referència a un objecte que els torejadors claven als toros, garranxó no consta en els diccionaris. Com la galotxa o banderilla, devia tenir un ganxo o llengüeta per poder-se clavar en l'animal sense soltar-se. ${ }^{62}$ En el llibre del veterinari valencià Salvador Montó i Roca Sanidad del cavallo y otros animales sujetos al arte de albeytería ilustrada con el de herrar (València, Joseph Estevan, 1742) hom fa referència a un tipus de ferradura «con galocha o garranchón, como una S» (p. 157), la qual, com mostra el gravat il-lustratiu que acompanya l'explicació (p. 193), té en la part posterior, una peça de ferro corbada en forma de $\mathrm{S}$ al revés. ${ }^{63} \mathrm{D}$ 'altra banda, en relació també a la forma de l'objecte, a Atzeneta d'Albaida, el garranxó és una «especie de «ganxet» que se forma en la cabeza de los espartos», que cal eliminar per poder treballar l'espart (http://www.valldalbaida.com/index.php?option=com_content\&v iew $=$ article $\&$ Itemid=262\&id=254: atzeneta-dalbaida\&lang=ES). Per últim, segons Coromines, el mot garranxó pot designar un branquilló, com ho llegim en una de les seues monografies toponímiques locals, encara inèdites, per relació a la partida del Garranxet de Castelló de les Gerres, en plantejar la

Torres, 2008: 70; Racó d'Ademús, Gargallo, 2004: 152-153); en canvi, en cat. no es troba fins a mitjan s. XIX (Escrig), i té una extensió geogràfica molt limitada. Per tant, no és desenraonat pensar-hi en un manlleu procedent del cast.

62 Cf. galotxa: «-ací té / una galotja pintada, / y farà una sort. / -Que es burla? / -No em burle. Ací té una lanza, / per si vol rajonear. / (...) Y si no basta, / li donaré un machinet, / un punyalet y una espasa» (a. 1730) (Furió, 2001: 141), per a la correguda de bous, «Y si agarrem a Trochena, / aquell qu.en lo puny tancat / sempre clava les galoches / que-ns alça la pell un pam, / li donarem passaport, / per a sempre desterrat» (Rinya, 4), diuen els toros, i galotxa de foc: «es menchà [el bou] enmich de la plaza, / com si fóra pa de casa, / una galocha de foch» (Corrida de toros, v. 147-149). A mitjan s. XVII, en sentit figurat, en un poema de Josep Rostojo dedicat a Marc Antoni Ortí, secretari del certamen poètic: «Refile bé la galoja, / vaja de estofa lo estyl, / ab aquelles primoretes / que ses obres sol vestir» (Segundo centenario de los años de la canonización del valenciano apóstol san Vicente Ferrer..., por Don Marco Antonio Ortí, València, 1656); també es doc. galotxa com un ornament en el vestit militar: «-Y.l vestit [militar] com ha de ser? / (...) -Dihuen que de paño pardo, / y en lo coll ham de portar / un cuerno tot ple de flors / en tres galoges pasat. / Uns li dihuen cuernicòpia, / altres, que són cinicials / de la diosa Esteres» (Rahonament entre Pep d'Aldaya y Miquel el D'Alaquàs..., 1809, p. 3); per als sentits figurats de galotxa, veg. Martí (2006). Dóna lloc als derivats galotxada: «la Diputació feu fer corre de toros en la plaça del Born... y los toros que corregueren los avien fets venir de Tortosa..., y arrametien molt bé la tent y los tiraven grans fletxes y galotxades» (crònica de Miquel Parets) (DAg, IV, 120), «Y Nelo, tragant saliva, tratà de cobrar-se aquelles galochaes de la siguient manera» (Arte y Letras 16, 1911, p. 6), per les pulles que li adreça la seua dona, acusant-lo de malfeiner; i engalotxat (no registrat en el DCVB, el DECat ni el DAg), aplicat a un toro al qual hom ha clavat galotxes: «Yo m'alse com un rellam, / prenguí les portes a fora, / com un toro engalochat. / Ells se quedaren rient / de veure'm a mi marchar / com un corso, figuran-se / que yo corria rabiant» (Martí 1997: 339). En el DECat (IV, 311) «galochas para agarrochar el toro, vanderillas (Sanelo)», que «està en íntima relació amb cast. garrocha 'banderilla para id.', cat. dial. garlotxa; i en relació més llunyana amb garranxa (GANXO), del qual pot ser alteració per contaminació»; en cast. garlocha, doc. des de finals del s. XVI (Lope de Vega: La Arcadia, ap. CORDE), que en el DCECH (III, 106) es considera var. de garrocha, «con la alternancia - rr- / -rl». Sobre el cast. garrocha i garlocha, veg. també Torres (1989: 107), que considera garlocha una forma antiga i poc usada.

63 L'autor diu que aquesta ferradura «sirve para reparar el huello topino, quando está en el último grado de su estado; sea de la mano o del pie la imperfección» (p. 194). 
possibilitat «que la partida hagi pres nom de la fonteta... fonts obturades... pot ser una estaqueta o un simple branquilló (garranxó) entaforat en el canó de la font» (Casanova 2002: 252). ${ }^{64}$

\section{BIBLIOGRAFIA}

Alcaide, Ll.; Ferrer, V. (1986) «Sobre la toponímia de Puçol», dins Desè Col-loqui General de la Societat d'Onomàstica, València, Universitat de València, pp. 15-23.

ALEANR = Alvar, M.; Llorente, A.; Salvador, G. (1961-1973) Atlas Lingüístico y etnográfico de Aragón, Navarra y Rioja, Saragossa / Madrid, Departamento de Geografía Lingüística / Institución Fernando el Católico / CSIC, 12 vols.

Aliaga, J. L. (2008) Borrador de un diccionario de voces aragonesas. José Siesso de Bolea, Saragossa, Gara d'Edizions.

Alibert, L. (2002) Dictionnaire occitan-français, Tolosa, IEO.

Alonso, M. (1986) Diccionario medieval español, Salamanca, UPS.

Alvar, M. (2000) Tesoro léxico de las hablas andaluzas, Madrid, Arco Libros.

Amat, R. d' (1988-94) Calaix de sastre, I, III, VI, VII, Barcelona, Curial.

Amengual, J. J. (1858) Nuevo diccionario mallorquín-castellano-latín, Palma, Colomar.

Andolz, R. (2004) Diccionario aragonés, Saragossa, Mira.

Barberà, F. (1905) Conferencias sobre bio-bibliografía de Carlos Ros, València, Vives Mora.

Barberà i Soler, J. (2004) «El corre de bou de Cardona», Caramella, 11, 21-25.

Barreda, P. E. (1996-1997) «Els Establiments de la Torre d'en Besora», Estudis Castellonencs, 7, 427-489.

Beltran, J. S. (2010) Vocabulari de crü̈lla, Benicarló, Onada.

Blasco, R. (1983) Col-loquis i raonaments, València, L'Estel.

Broch, J. (1771) Prontuario trilingüe, Barcelona, Pablo Campins.

Brú Turull, R. (2004) «La font de Santa Anna del portal de l'Àngel», Matèria, 4, 77-94.

Bulbena, A. (1919) Diccionario catalán-castellano, Barcelona, Badia Cantenys.

\footnotetext{
64 Sobre garranxo, garranxó i altres mots d'aquesta família lèxica al País Valencià, vegeu també Martines (2012a: 153-158). Hom pot consultar, així mateix, en relació amb el català i amb altres llengües, Vidal (2012: 104-106).
} 
Cardona Ivars, J. J. (1986) «El bandolerismo del segle XIX a Benissa i rodalies», dins ler Congrés d'Estudis de la Marina Alta, Alacant, Institut d'Estudis «Juan Gil-Albert», pp. 125-129.

Carrera Pujal, J. (1951) La Barcelona del segle XVIII, Barcelona, Bosch.

Carreres Zacarés, S. (1925) Ensayo de una bibliografía de libros de fiestas celebradas en Valencia y su antiguo reino, València, impr. Hijo de F. Vives Mora.

Casanova, E. (2002) «Les monografies toponímiques de Joan Coromines i l'Onomasticon Cataloniae: el cas de la Vall d'Albaida», dins Emili Casanova i Vicenç M. Rosselló (eds.): Congrés Internacional de Toponímia $i$ Onomàstica Catalanes, València, Universitat de València, pp. 219-277.

Casas Homs, J. M. (ed.) (1975-1976): Dietari de Jeroni Pujades, Barcelona, Fundació Salvador Vives Casajuana, 4 vol.

Cejador, J. (2008) Diccionario fraseológico del Siglo de Oro, Barcelona, Serbal.

CICA = Corpus Informatitzat del Català Antic, Torruella, J. (dir.), Pérez Saldanya, M. / Martines, J. / Martines, V. 2013. http://webs2002.uab.es/sfi/cica/

$C O R D E=$ Real Academia Española: Banco de datos (CORDE) [en línea]. Cor pus diacrónico del español. http://www.rae.es [setembre 2013].

DAg = Diccionari Aguiló (1915-1934), Barcelona, IEC, 8 vol.

$D C V B=$ Alcover, A. M. / Moll, F. de B. (1988) Diccionari Català-ValenciàBalear, Palma de Mallorca, Moll, 10 vol.

$D C E C H=$ Coromines, J., amb la col-laboració de J. A. Pascual (2000-2002) Diccionario crítico etimológico castellano e hispánico, Madrid, Gredos, 6 vol.

DECat $=$ Coromines, J. (1980-2002) Diccionari etimològic $i$ complementari de la llengua catalana, Barcelona, Curial, 10 vol.

Delgado Ruiz, M. (1994-95) «Tener o no tener. Los bueyes en la festa del pi en Centelles, Cataluña», Mediterrâneo, 5/6, 77-97.

Diaz Manteca, E. (1983) Establiments de la vila de Vilafamés, Castelló, Diputació Provincial de Castelló de la Plana.

Diéguez, Mà À. (2001) El Llibre de Cort de Justícia de València (1279-1321). Estudi lingüístic, Alacant / Barcelona, IIFV / PAM.

Diéguez, $\mathrm{M}^{\mathrm{a}}$ À. (2002) Clams i crims en la València medieval segons el Llibre de Cort de Justícia (1279-1321), Alacant, Universitat d'Alacant.

$D N V$ = Acadèmia Valenciana de la Llengua (2014) Diccionari normatiu Valencià [en línia] http://www.avl-gva.es/dnv.

Duarte, C. (1991) «La llengua del manuscrit 1272 del Llibre de les Costums de Tortosa», Revista de Llengua i Dret, 16, 7-56. 
D. y M. (1847): Diccionario catalán-castellano, Barcelona, Agencia Médica Catalana.

Endize = Nagore, F. (dir) (1999) Endize de bocables de l'aragonés, Huesca, Instituto de Estudios Altoaragoneses.

EscLl = Escrig, J.; Llombart, C. (1887) Diccionario valenciano-castellano, València, P. Aguilar.

Escrig, J. (1851) Diccionario valenciano-castellano, València, Ferrer de Orga.

Farreny, M $\mathrm{M}^{\mathrm{a}} \mathrm{D}$. (2004) La llengua dels processos de crims a la Lleida del segle $X V I$, Barcelona, IEC.

Febrer i Cardona, A. (2001) Diccionari menorquí, español, francés i llatí, Barcelona, IEC.

Ferrando, A. (1995) «Les Memòries curioses (1609-1651) de mossén Vicent Torralba», L'Aiguadolç, 21, pp. 37-64.

Ferrer, M. (1839) Diccionario catalán-castellano, Barcelona, Pablo Riera.

Figuera, P. A. (1840) Diccionari mallorquí-castellà, Palma, Esteva Trias.

Font, A. (1637) Fons verborum et phrasium, Barcelona, Matevat.

Freire Moliner, M ${ }^{\mathrm{a}}$ J. (1995) El Libro registro de los privilegios de la Albufera de Valencia, Saragossa, Anubar Ediciones.

Furió, J. M. (2001) «Els poemes valencians de Josep Vicent Ortí Mayor. Estudi i edició», Caplletra, 31, 115-150.

Gargallo, J. E. (2004) Habla y cultura popular en el Rincón de Ademuz, Madrid, CSIC.

Garganté, M. (2011) Festa, arquitectura y devoció a la Catalunya del Barroc, Barcelona, PAM.

Gimeno, Ll. (1998) De lexicografia valenciana, València / Barcelona, IIFV / PAM.

Giner, F. (1986) «La toponímia litoral i marítima de Cullera», dins Desè Col-loqui General de la Societat d'Onomàstica, València, Universitat de València, pp. 136-149.

Giner, J. (1998) Obra filològica (1931-1991), estudi preliminar, edició crítica a cura d'Antoni Ferrando, amb la col-laboració de Santi Cortés, València, Denes.

Giralt, J. (2005) Lèxic de la Llitera, Lleida, Milenio.

Gómez Molina, J. R. (coord.) (2005) El español hablado de Valencia. Materiales para su estudio. II Nivel sociocultural medio, València, Universitat de València.

Gómez-Senent, C. (1982) Literatura de cordell valenciana dels segles XVIII $i$ XIX: Aportació bibliogràfica, València. 
González, A. (1996) Bous, toros i braus. Una tauromàquia catalana, Tarragona, El Mèdol.

Graullera, V. (1999) «Fiestas con toros en Valencia en los siglos XIV-XVII», dins Des Taureaux et des Hommes. Tauromachie et société dans le monde ibérique et ibéro-américain, París, PUPS, pp. 77-92.

Griera, A. (1966) Tresor de la llengua, Barcelona, Polígrafa, 14 vols.

Guillaume-Alonso, A. (1999) «Contre la corrida. Essai de typologie des positions anti-taurines (XVIe-XVIIe siècles)», dins Des Taureaux et des Hommes. Tauromachie et société dans le monde ibérique et ibéro-américain, París, PUPS, pp. 13-21.

Guinot, E. (2006) Establiments municipals del Maestrat, els Ports de Morella $i$ Llucena (segles XIV-XVIII), València, Universitat de València.

Gulsoy, J. (1964) El Diccionario valenciano-castellano de Manuel Joaquín Sanelo, Castelló de la Plana, Sociedad Castellonense de Cultura.

Iribarren, J. M. (1952) Vocabulario navarro, Pamplona, ed. Gómez.

Labèrnia, P. (1839-40) Diccionari de la llengua catalana, 2 vols., Barcelona, Hereus de la V. Pla.

Lacavalleria, J. (1696) Gazophylacium catalano-latinum, Barcelona, Antoni Lacavalleria.

Leralta, J. (2002) Madrid. Cuentos, leyendas y anéctotas, II, Madrid, Sílex.

Lespy, V.; Raymond, P. (1970) Dictionnaire béarnais ancien et moderne, Genève, Slatkine reprints.

Levy, E. (1991) Petit dictionnaire provençal-français, Raphèle-lès-Arles, Petit.

López, R.; Torres, J. M. (2008) El habla de los pueblos turolenses de la comarca Gúdar-Javalambre, Madrid, Vision Net.

López Verdejo, V. (2010) Diccionari general de la llengua valenciana, València, RACV.

Lozano, J. (ed.) (2012) Pere J. Porcar, Coses evengudes en la ciutat y regne de València. Dietari (1589-1628), València, PUV.

Malkiel, Y. (1989) «La etimología de corro y corral», Anuario de Letras, 27, 5-62.

Manrique, G. (1956) «Vocabulario popular comparado de los Valles del Duero y del Ebro», Revista de Dialetología y Tradiciones Populares, 12, 3-53.

Martí, J. (1994) El Libre de Antiquitats de la Seu de València. Estudi i edició, València / Barcelona, IUFV / PAM, 2 vols.

Martí, J. (1996) Col-loquis eroticoburlescos del segle XVIII, València, IVEI.

Martí, J. (1997) Literatura de canya i cordell al País Valencià, València, Denes. 
Martí, J. (2006) Diccionari històric del valencià col-loquial, València, Universitat de València.

Martí, J. (2011) Diccionari de Josep Bernat i Baldoví, València, Denes.

Martí, J. (2012) «L'aportació lèxica de Josep Bernat i Baldoví, dins del context literari dels segles XVIII i XIX», RLLCGV, 17, pp. 31-70.

Martí, J. (e. p.) «Col-loquis taurins dels segles XVIII i XIX», en premsa.

Martines, J. (2000) El valencià del segle XIX. Estudi lingüístic del Diccionario valenciano de Josep Pla i Costa, Alacant / Barcelona, IIFV / PAM.

Martines, J. (2012a) El valencià del segle XIX: el lèxic, Barcelona, IEC.

Martines, J. (2012b) «Història del lèxic i contacte de llengües. El català i l'aragonès al País Valencià a l'Edat Mitjana: un tast lèxic», dins Historia del léxico: perspectivas de investigación, Madrid / Frankfurt am Main, Iberoamericana / Vervuert, pp. 127-167.

Martínez, J. (2010) Joan B. Pastor Aicart. Més enllà de la poesia, València, PUV.

Merle, A. (1999) «Tauromachie et identité nationale dans les mentalités espagnoles et étrangères à l'époque moderne», dins Des Taureaux et des Hommes. Tauromachie et société dans le monde ibérique et ibéro-américain, París, PUPS, pp. 37-50.

MGad = Martí Gadea, J. (1891) Diccionario general valenciano-castellano, València, J. Canales Romà.

Miquel i Planas, R. (ed.) (1911) Cançoner satírich valencià dels segles XV y $X V I$, Barcelona, Biblioteca Catalana.

Moneva, J. (2004) Vocabulario de Aragón, Saragossa, Xordica Editorial.

Nagore, F. (2003) El aragonés del siglo XIV según el texto de la Crònica de San Juan de la Peña, Saragossa, Instituto de Estudios Altoaragoneses.

NDHE = Corpus del Nuevo Diccionario Histórico del Español, Madrid, Instituto de Investigación Rafael Lapesa (http://web.frl.es/CNDHE/view/ inicioExterno.view).

NTLE = Nieto, L.; Alvar, M. (2007) Nuevo Tesoro Lexicográfico del Español (s. XIV-1726), Madrid, Arco Libros.

NTLLE = Real Academia Española (2000) Nuevo Tesoro Lexicográfico de la Lengua Española, Madrid, Espasa, edición en DVD.

Olucha, F. (2011) Repertori d'inventaris de l'església parroquial de Santa Maria de Castelló. 1528-1706, Castelló, Diputació de Castelló.

OnCat $=$ Coromines, J. (1989-1997) Onomasticon Cataloniae, Barcelona, Curial, 8 vols. 
Ongay, N. (1997) El registro del «Veinteno» en Tudela (1362). Estudio, transcripción y notas, Mendoza, Universidad Nacional de Cuyo.

Pastor, J. M. (2004): Tesoro léxico de las hablas riojanas, Logroño, Universidad de La Rioja.

Peirats, A. I. (ed.) (2010) Jaume Roig, Spill, València, AVL.

Pérez Medina, T. V. (1995) La tierra y la comunidad rural de Petrer en el siglo XVII, Alacant, Universitat d'Alacant.

Ponsoda, J. J. (1996) El català i l'aragonés en els inicis del Regne de València segons el Llibre de Cort de Justícia de Cocentaina (1269-1295), Alcoi, Marfil.

Pou, O. (1580) Thesaurus Puerilis, Barcelona, Menescal.

Reig, E. S. (2008) Les nostres paraules, València, AVL.

Ribelles Comín, J. (1943) Bibliografía de la lengua valenciana, III, Madrid, Tip. de la Revista de Archivos, Bibliotecas y Museos.

Rodrigo, M. (2010) «Ordinacions d'Albalat dels Sorells (1665). Estudi i edició», Boletín de la Sociedad Castellonense de Cultura, 86, 397-324.

Rodrigo, M. (ed.) (2011) Melcior Miralles: Crònica i dietari del capellà d'Alfons el Magnànim, València, Universitat de València.

Ros, C. (1764) Diccionario valenciano-castellano, València, Monfort.

Rovira i Virgili, A. (1919): Diccionari català-castellà, Barcelona, López.

Rubio Vela, A. (1998-2003) Epistolari de la Valencia medieval, València / Barcelona, IIFV / PAM, 2 vols.

Ruiz Marín, D. (2007) Vocabulario de las hablas murcianas, Múrcia, Diego Marín.

Sans i Travé, J. M. (dir.) (1994-2007) Dietaris de la Generalitat de Catalunya, Barcelona, Generalitat de Catalunya, 10 vols.

Saura, J. A. (1878) Novíssim diccionari manual de las llenguas catalana-castellana, Barcelona, Esteve Pujal.

Segura, J. C. (2003) Una cruïlla lingüística. Caracterització del parlar del Baix Vinalopó, Alacant, Universitat d'Alacant.

Saumade, F. (2006) Las tauromaquias europeas, Sevilla, FET.

Sesma, J. Á.; Líbano, Á. (1982) Léxico del comercio medieval en Aragón (siglo $X V)$, Saragossa, Institución «Fernando el Católico».

Torra, A. (1653) Dictionarium seu Thesaurus catalano-latinus verborum ac phrasium, Barcelona, Antoni Lacavalleria.

Torres Navarrete, F. (1995) La llengua de Carles Ros, tesi doctoral dir. pel Dr. Emili Casanova, València, Universitat de València. 
$T L F i=$ Trésor de la Langue Française informatisé. CNRTL. http://atilf.atilf.fr/ Torres, J. C. de (1989) Léxico español de los toros, Madrid, CSIC.

$T P V=$ Toponímia dels Pobles Valencians, València, AVL.

Vargas Ponce, J. (1961) Disertación sobre las corridas de toros, ed. de Julio F. Guillén y Tato, Madrid, Real Academia de la Historia.

Vázquez Obrador, J. (1994) «Pervivencias léxicas prerromanas en el altoaragonés», dins Enguita, José $\mathrm{M}^{\mathrm{a}}$ (ed.): III Curso sobre Lengua y Literatura en Aragón (Siglos XVIII-XX), Saragossa, Institución «Fernando el Católico», pp. 217-285.

Veny, J. (2006): Contacte i contrast de llengües i dialectes, València, PUV.

Vicent i Cavaller, J. A. (1985): Toponímia de Nules $i$ de la Vilavella de Nules, tesi de llicenciatura dir. pel Dr. Josep Trenchs Odena, València, Universitat de València.

Vidal, J. C. (2012) Los vínculos europeos del substrato íbero, ed. electrònica. [https://binper.files.wordpress.com/2012/04/vinculos.pdf] 
